\title{
Investigating the links between political settlements and inclusive development in Uganda: towards a research agenda
}

Link to publication record in Manchester Research Explorer

Citation for published version (APA):

Golooba-Mutebi, F., \& Hickey, S. (2013). Investigating the links between political settlements and inclusive development in Uganda: towards a research agenda. (ESID Working Paper Series; No. 20).

\section{Citing this paper}

Please note that where the full-text provided on Manchester Research Explorer is the Author Accepted Manuscript or Proof version this may differ from the final Published version. If citing, it is advised that you check and use the publisher's definitive version.

\section{General rights}

Copyright and moral rights for the publications made accessible in the Research Explorer are retained by the authors and/or other copyright owners and it is a condition of accessing publications that users recognise and abide by the legal requirements associated with these rights.

\section{Takedown policy}

If you believe that this document breaches copyright please refer to the University of Manchester's Takedown Procedures [http://man.ac.uk/04Y6Bo] or contact uml.scholarlycommunications@manchester.ac.uk providing relevant details, so we can investigate your claim.

\section{OPEN ACCESS}


ESID Working Paper No. 20

\section{Investigating the links between political settlements and inclusive development in Uganda: towards a research agenda.}

Frederick Golooba-Mutebi ${ }^{1}$ and Sam Hickey ${ }^{2}$

August, 2013

${ }^{1}$ Independent Researcher and Honorary Research Fellow, University of Manchester

Email correspondence: fgmutebi@yahoo.com

${ }^{2}$ The University of Manchester

Email correspondence: sam.hickey@manchester.ac.uk

ISBN: 978-1-908749-19-2 


\section{Abstract}

The changing character of the political settlement in Uganda since independence has closely shaped the character and performance of the institutions and actors responsible for delivering development. Successive political leaders sought to establish 'dominant ruler' forms of political settlement, with little sustained effort to depersonalise public institutions or build stable and inclusive ruling coalitions. This seemed to change in 1986, as Yoweri Museveni's National Resistance Movement (NRM) sought to establish a new settlement, based on a broad-based coalition and an ostensible commitment to development. However, the NRM's record of generating the commitment and capacity required to deliver development has been mixed. On the one hand, a mixture of elite commitment, pockets of bureaucratic excellence and external support has enabled impressive levels of economic growth, macroeconomic stability and social expenditure. However, the current settlement - characterised by deepening levels of competitive clientelism, highly personalised forms of public bureaucracy, collusive state-business relations, and a ruling coalition that is (expensively) inclusive at the lower levels while becoming narrower and more nepotistic at the pinnacle - has failed to provide the basis for tackling the more difficult challenges of achieving structural transformation, delivering high-quality public services and challenging social inequalities.

The case of Uganda reveals the need to extend the current boundaries of political settlement analysis beyond a narrow focus on incentives at the national level, to incorporate a stronger focus on ideas and transnational factors. Dominant ideas around state legitimacy and development have played an important role in shaping governance and development in Uganda, and this has often involved a role for the shifting sets of transnational actors on which the regime relies to maintain itself in power. This paper includes suggestions for further research on the politics of development in Uganda, including around the extent to which the discovery of oil will both be shaped by and help reshape the political settlement.

Keywords: political settlements, Uganda, development, structural transformation, service delivery, inequality.

This document is an output from a project funded by the UK Aid from the UK Department for International Development (DFID) for the benefit of developing countries. However, the views expressed and information contained in it are not necessarily those of or endorsed by DFID, which can accept no responsibility for such views or information or for any reliance placed on them. 


\section{Table of Contents}

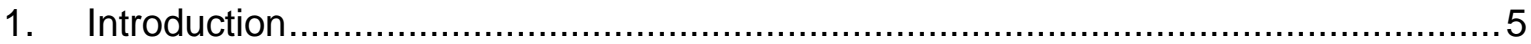

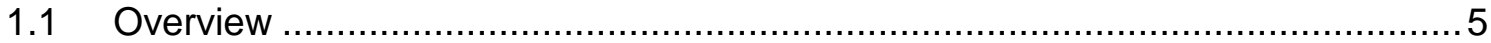

1.2 Conceptual framework: 'political settlements-plus' ..................................... 5

2. Inclusive development in Uganda: status and key trends................................. 7

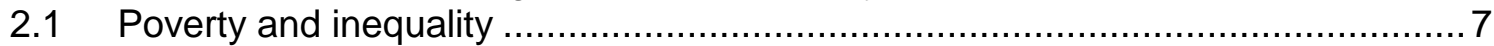

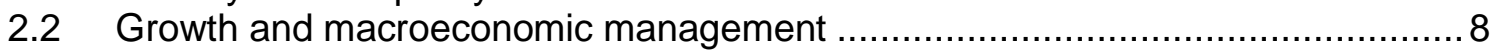

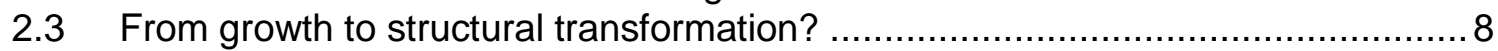

3. Historical origins of the Ugandan political settlement .................................... 10

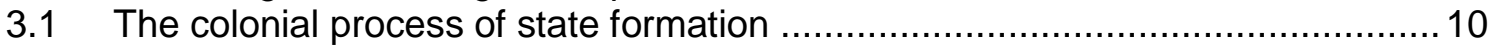

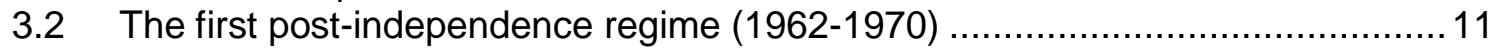

3.3 The reign of Idi Amin: 1971-1980 ........................................................ 12

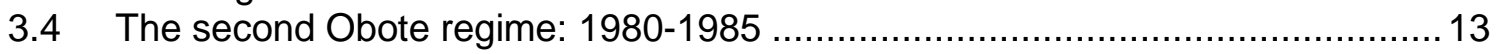

4. The political settlement from 1986 to the present............................................... 14

4.1 The making of a broad-based dominant party political settlement..................... 14

4.2 Mapping the ruling coalition in Uganda ....................................................... 16

4.3 State-business relations within the ruling coalition .................................... 17

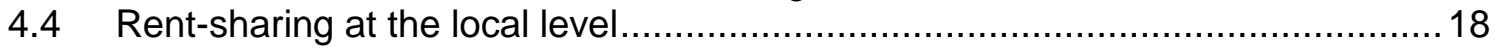

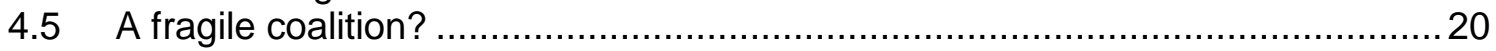

5. Implications for state capacity, elite commitment and inclusive development ..........22

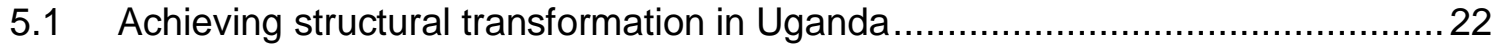

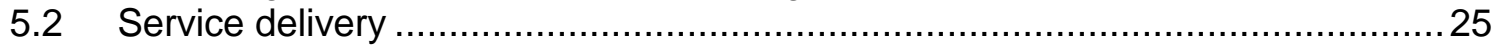

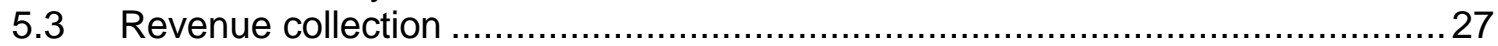

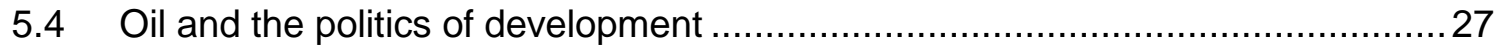

5.5 The politics of challenging exclusion and inequality $(\mathrm{I}):$ Women....................... 30

5.6 The politics of challenging exclusion and inequality (II): The north ...................... 31

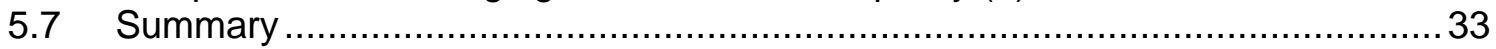

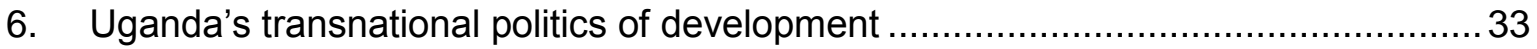

6.1 Regional issues: security and integration.............................................. 34

6.2 How does aid shape the politics of development in Uganda? Some key trends

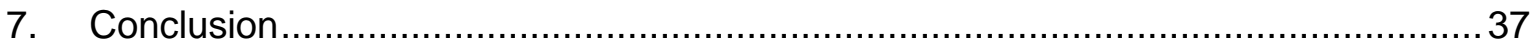

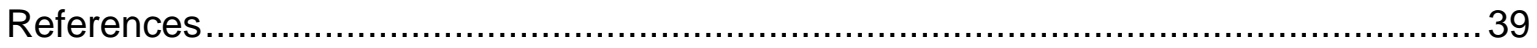

Appendix 1: Some suggestions for ESID research in Uganda ................................. 48 
Investigating the links between political settlements and inclusive development in Uganda

\section{Introduction}

\subsection{Overview}

This paper identifies the main political and political economy drivers of development in Uganda today. It starts from the premise that the 'political settlement' forged among the most powerful groups in society (Khan, 2010; North et al., 2009) shapes the capacity and commitment of governments to deliver development (Hickey, 2012a). Building on recent investigations into the politics of development in Uganda (e.g. Barkan, 2011; Kjaer and Katusiimeh, 2012), this paper examines the historical origins and current state of the political settlement and the implications for governance and inclusive development in Uganda, with a particular focus on structural transformation, social provisioning and the politics of recognition. It finishes by identifying some key areas for further research.

\subsection{Conceptual framework: 'political settlements-plus'}

“(...the) 'political settlement' refers to the balance or distribution of power between contending social groups and social classes, on which any state is based." (di John and Putzel, 2009, p. 4).

The concept of political settlement pushes development thinking beyond an institutionalist perspective by focusing on the underlying power arrangements that underpin and shape the emergence and performance of institutions. From this perspective, elite bargaining is central to establishing stability and order and also determines the extent to which elites have the incentives to build the institutions required to deliver 'good-enough' levels of governance and development, and enable them to develop and function effectively. The political settlement is shaped by a number of key factors, including the relationships between political elites, productive capitalists and broader social groupings (Khan, 2010; di John and Putzel, 2009). Khan (2010, pp. 7-8) identifies two aspects of the 'clientelist' political settlements that tend to dominate in developing countries and that help explain why institutions perform differently: the organisation of the ruling coalition; and the technological capabilities of productive entrepreneurs in that society and their relationship of power with the ruling coalition. The ruling coalition can be defined in terms of the ruling elite and their interrelationships (including those between state actors and leading capitalists), and the relationship between this ruling elite and the factions required to support them in power (Kjaer and Katusiimeh, 2012).

However, drawing on earlier work within ESID (Hickey, 2012a), the approach adopted here goes further than this standard approach to political settlements analysis in at least three ways. First, we emphasise the extent to which political settlements are located within and closely shaped by the globalised context that involves national actors interacting with transnational actors, institutions, processes and also ideas (Hickey 
2012a). This includes but goes beyond a focus on aid. The focus on ideas (our second shift) is particularly important, as it develops our analytical focus beyond the rationalactor and incentives-based approach of Khan to include the more discursive aspects of politics in general and elite behaviour in particular. As such, our analysis incorporates a focus on how ideas have become entwined with the role of incentives in shaping elite behaviour and also had more 'independent' effects. Finally, we draw on recent work by Levy (2012), which identifies different types of political settlements in order to sharpen the analysis. Levy defines political settlements in terms of two dimensions: "the character of the political settlement; and the extent of institutional and organizational complexity" (ibid, p. 4). The character of political settlements refers to how political power is organised: is this according to a 'dominant party/ruler' system or the logic of 'competitive clientelism'? In the former, political power is concentrated within the hands of a dominant party or leader, while the latter involves: "Political settlements which are anchored in a 'truce' in which competing forces agree on peaceful rules for political competition" (ibid, p. 6). The dimension of institutional complexity derives from North et al.'s (2009) focus on the role played by achieving more impersonal and universal forms of public organisation within shifts from limited to open access orders. Figure 1 below shows how Boxes \#2 and \#3 designate the 'early stage' of these two main types, with \#4 and \#5 as the 'later stage' of each, following moves towards more impersonal forms of organisation.

We characterise Uganda as a 'dominant leader' form of political settlement, but also draw attention to the dynamics at work here, both in terms of the development of this system over the post-colonial period (Sections 4 and 5) and the more recent movement along each of the axes identified here, and particularly the deepening of competitive clientelist tendencies. We argue with others that recent dynamics within Uganda's political settlement are largely inimical to the prospects of developing the kinds of relations and institutions associated with delivering either structural transformation or improved levels of service delivery (Barkan, 2011; Hickey, 2013; Kjaer and Katusiimeh, 2012). This has serious implications for Uganda's development prospects moving forwards, and the final section advances some ideas for further research into what is feasible for governance and development within this context. 
Figure 1: Different types of political settlement

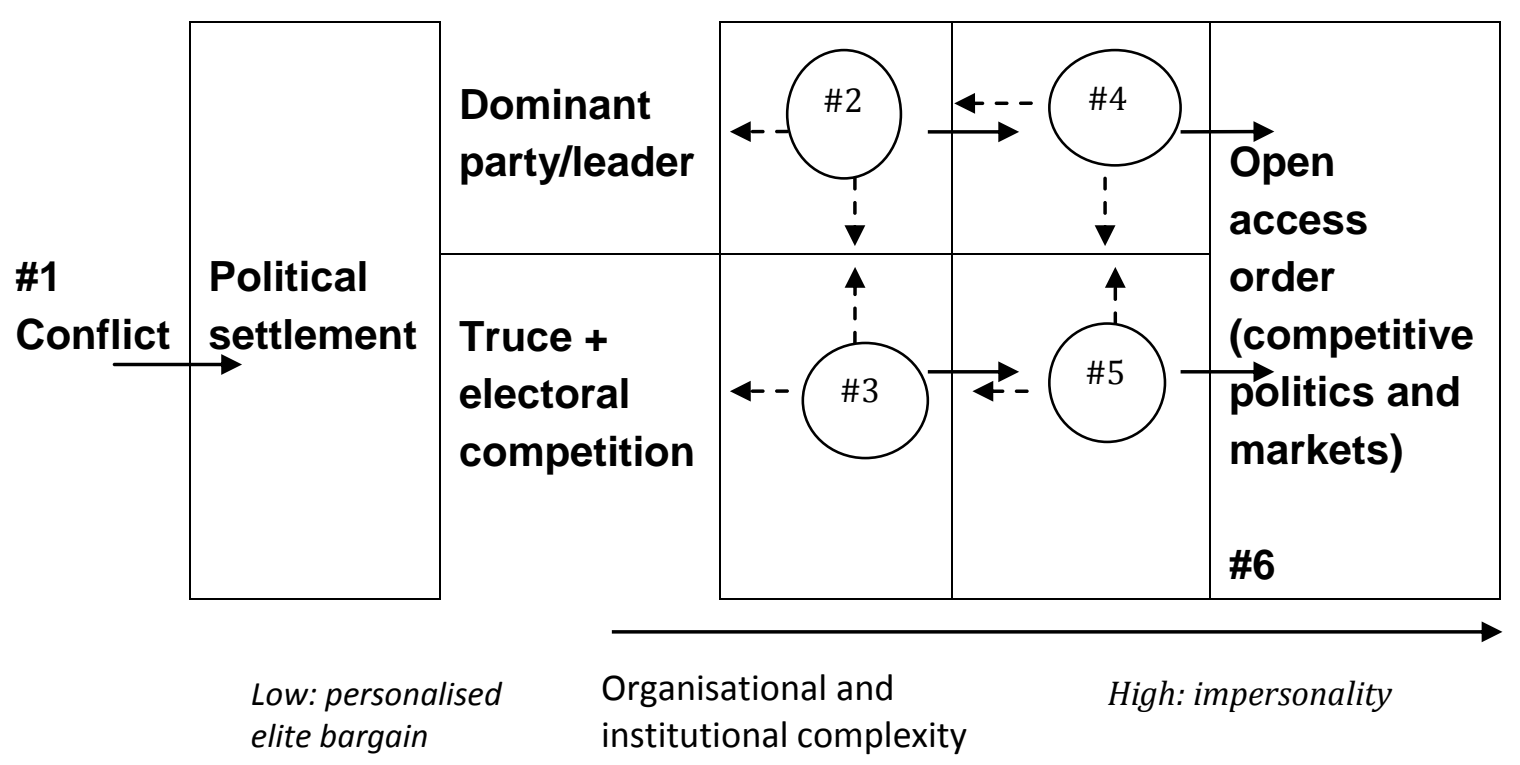

Adapted from Levy (2012)

\section{Inclusive development in Uganda: status and key trends}

\subsection{Poverty and inequality}

Uganda's record of delivering development over the past two decades has been impressive in terms of growth and poverty reduction, but less so in terms of other social indicators and also inequality. The country is on track to halve poverty by 2015 and is also making "significant progress towards reducing the share of the population suffering from hunger" (MFPED, 2010). However, many of those who have exited from poverty have not moved very far above the poverty line and remain highly vulnerable, with 43 per cent of the population, around 13 million people, classified as "non poor but insecure" (MFPED, 2012, p. i). The aim of achieving gender parity between boys and girls in primary education has been achieved, although completion rates within primary schools have stagnated (Section 5). Progress has been slow on several health targets, including those related to child and maternal mortality, access to reproductive health, and the incidence of malaria (UNHDS, 2012).

Income inequality as measured by the Gini co-efficient rose sharply over the last two decades, from 0.37 in 1992-3 to 0.43 in 2009-10. There are strong popular perceptions that inequality is increasing (MFPED, 2012), and the distribution of opportunities remains highly uneven in terms of gender and region in particular. Uganda recorded a very low score on the Gender-related Development Index in the 2007/2008 HDR, with its 0.501 score placing it in $132^{\text {nd }}$ position out of 157 countries. That this failure to promote gender 
equity policies has persisted despite women participating in politics at relatively high rates strengthens the conclusion that women have gained inclusion but not influence in Uganda (Goetz and Hassim 2003). In terms of regional inequality, the generally pro-poor forms of growth experienced during most of the 1990s had become less inclusive by the late 1990s and early 2000s, with a bias emerging towards the urban and western areas of the country, particularly vis-à-vis the north and east. Both poverty and prosperity remain highly unevenly distributed: "In Kampala, 77 per cent of the population are middle class. In the North East, 76 per cent are poor." (MFPED, 2012, p. 2).

\subsection{Growth and macroeconomic management}

Uganda was the fifth fastest growing economy in the world between 2005 and 2009 and has maintained high levels of macroeconomic stability since adopting strict monetary and fiscal policies from the early 1990s, and developing a strong and wellinstitutionalised finance technocracy, primarily in the Bank of Uganda (BoU) and Ministry of Finance, Planning and Economic Development (MFPED). However, the strong foundations that have been laid for both growth and macroeconomic stability have been threatened in recent years. Growth has been subdued over the past three years and was only 3.2 per cent for 2011-12, the worst return since 1987 as compared to the average of over eight per cent between 2000-2007/8 and of seven per cent during the 1990s (Kasekende et al., 2004).

This short-term decline reflects a mixture of 'exogenous' shocks, including drought and food shortages, high levels of demand for food and other consumable goods from southern Sudan, the global economic downturn, and high inflation in some of Uganda's key trading export partners. However, it also relates closely to structural problems in both political and economic terms. Politically, the problems of high inflation and limited growth seem to have been driven in part by the lack of fiscal discipline around the 2011 elections, particularly in terms of the use of supplementary budgets to cover high levels of unscheduled expenditure on campaign costs and military hardware (Izama, 2011). As discussed below (Section 5.1), this raises questions as to whether the government's longstanding commitment to macroeconomic stability is wavering.

\subsection{From growth to structural transformation?}

Opinions differ on whether structural transformation is underway in Uganda, and at what rate (Selassie, 2008; World Bank, 2010). Problems include limited levels of urbanisation and high levels of under-employment in urban areas, and the fact that although agriculture decreased its share of overall output significantly during the 2000s (from 57 to 30 per cent by 2008), over 70 per cent of the workforce is still currently employed in the agricultural sector (World Bank, 2010). The failure to significantly increase agricultural productivity and move from a primary-based economy to a higher productive 
economy is particularly problematic in the context of Uganda's high rates of population growth. ${ }^{1}$ There are also growing concerns regarding the composition of economic growth in Uganda, which derives predominantly from consumption rather than investment, and the structural basis of the economy more broadly. The balance of payments on export trade continues to deteriorate (World Bank, 2010). Uganda is becoming increasingly dependent on imports, which are also of a more technical nature and of higher value (e.g. vehicles, cement) than its exports (e.g. agricultural products, and especially coffee, contribute 46 per cent of export earnings). Uganda's new economic partnerships, particularly with China, are further embedding this trend. ${ }^{2}$

In contrast, more optimistic observers, including the government itself, claim that "the transformation process is well underway", noting that: "there has been dramatic growth and diversification of the non-agricultural economy" (MFPED, 2012, p. i). In particular, between 2005/6 and 2009/10, "the proportion of rural households relying primarily on subsistence agriculture declined from 64 to 54 per cent, reflecting significant diversification into non-farm activities." (MFPED, 2012, p. 6). ${ }^{3}$ Fox (2009, p. 4) also suggests that between 1992 and 2005-6, "Uganda did exceptionally well at creating new wage and salary jobs in both agriculture and the non-farm sectors", particularly in terms of "the overall growth of the non-farm sector, and the growth of wage and salary jobs in both agriculture and non-agricultural sectors", both of which suggest a degree of structural transformation. Although "Uganda's economy is very successful in creating wage and salary employment" (Fox, 2009, p. 2), however, only a minority of the fastgrowing working-age population is benefiting. We return to the question of whether the political settlement in Uganda is conducive to generating the capacities and commitment required to achieve structural transformation below (Section 5.1).

\footnotetext{
${ }^{1}$ Although the latest UNHDS data (2012) suggests that there has been a slowing down of the fertility rate in Uganda between 2006 and 2011, from 6.7 to 6.2, alongside increased usage of contraception.

${ }^{2}$ Uganda's import:export ratio with China stands at around 9:1. Although Chinese investment is associated with value addition in certain respects, including the reduction of gaps in savings and investment, and also technology, knowledge and management, this needs to be balanced by the fact that China primarily imports raw materials from Uganda without local value addition, has created few linkages in local economies, and tends to involve the production of poor quality products with little value addition (Ssenyange, 2010, p. 60). The abolition of tariffs for Ugandan exports to China from June 2012 may assist with a degree of re-balancing here.

${ }^{3}$ The government of Uganda also claimed that "the Ugandan middle class has grown from 1.8 million people in 1992 to over 10 million today" (MFPED, 2012, p. ii). However, the definition of middle class used here (all those with incomes above twice the poverty line) is highly problematic, setting the bar very low and focusing as it does on consumption, rather than on issues of employment.
} 


\section{Historical origins of the Ugandan political settlement}

\subsection{The colonial process of state formation}

As elsewhere in Africa, the colonial project of state formation in Uganda was based on forging ethno-national communities into units of 'native administration', through which political rule and economic processes of accumulation and extraction could be organised (Mamdani, 1996). The starting point for this process was the kingdom of Buganda. Finding it to be the most coherent and best organised of the kingdoms in the region, the British established it as the core of the protectorate, from whence they extracted surplus and established rule both within and beyond the kingdom (Mutibwa, 1992). The Baganda's eager embrace of colonial innovations and the system of freehold land rather than customary tenure enabled them to advance ahead of others in economic terms and establish the grounds for the uneven development that persists until today (Thompson, 1999; Van Zwanenberg and King, 1975; Mutibwa, 1992). The close alliance that developed between the British and Buganda led many to assume that the Baganda were gaining preferential treatment to the detriment of other peoples (Atkinson, 1994; Southall, 1998; Leopold, 2005). Those subjected to Baganda hegemony during the colonial era "...resented Buganda's economic advantages and created informal political coalitions to restrain its dominance that continue today" (ICG, 2012, p. 2).

Religion constituted another form of difference that was introduced and reproduced by the colonial encounter, most notably in terms of a divide between Protestants and Catholics. The colonial administration generally sided with the Protestants, despite the Catholics being more numerous, "with Muslims widely regarded as third-class citizens" (ICG, 2012, p. 2). This strongly informed the formation of the two major parties in Uganda, namely the Democratic Party (DP), widely seen as being the party of Catholics, and the Uganda People's Congress (UPC), associated with Protestantism.

Taken together, these origins of politics and development in Uganda played a significant role in shaping the character of the political settlements and the potential for 'inclusive' development in the post-colonial era. In particular, the early pre-eminence of Buganda within processes of state formation and development, and the further inculcation of difference along religious lines, left a new state that was heavily divided along ethnic and religious lines. This was further exacerbated by the limited time that the decolonisation process left for political parties to form and organise around genuine national platforms, as opposed to more sectarian concerns (Allen, 1995). No leader in the postindependence era has been able to overcome or successfully manage these divides for any significant period of time. 


\subsection{The first post-independence regime (1962-1970)}

On attaining independence in 1962, Milton Obote became Prime Minister, partly thanks to the support of the Baganda political organisation, Kabaka Yekka (Mutibwa, 1992). Informed both by the demands of achieving ethno-territorial balance in Uganda and the nationalist ideological sentiments of the day, Obote's "first administration displayed clear signs of an inclusive nation-building project, evident in attempts for political and economic power sharing" (Lindemann, 2010, p. 20). Efforts were also made to ensure inclusion at the level of religion, with Catholics and Muslims receiving a proportional share of ministerial appointments (op. cit.). According to several observers, the government made genuine efforts during this period to deliver critical public services to its citizens, whereby "Obote's government either heavily subsidised or provided free of charge both higher education and health care delivery at all levels (Dodge and Wiebe 1985; Gukiina 1972; Passi 1995; Bukenya, 2012).

However, Ugandan politics soon became characterised by the conflict between Obote and the Buganda kingdom (Mutibwa, 2008). The gradual disappearance of the Baganda from cabinet positions (Lindemann, 2012) escalated into 'The 1966 Crisis', a violent struggle between the regime and Buganda monarchists, for whom "...the institution of the monarchy had greater legitimacy than the national government and its institutions" (Golooba-Mutebi, 2008, p. 7). Following a military victory, Obote abolished the institution of the monarchy and effectively removed the Baganda from their institutionalised role in the ruling coalition. This dispute both threatened the very idea of Uganda as a political entity and established several enduring features of the political settlement in Uganda, including a central role for the military in politics (Golooba-Mutebi, 2008, p. 9) and a fundamental instability created by tensions between Buganda and the central government.

The crisis set in play in 1966 would further influence Obote's ideas about how development should be considered and approached in Uganda, with the attempt on his life in 1969 proving to be a "radicalizing experience...that played midwife to his dream of a move to the left" (Mazrui, 1991, p. 374), although others accord a stronger role here to the influence of leftist leaders whom Obote was close too, particularly Julius Nyerere (Gingyera-Pinycwa, 1978). This move was visible primarily in efforts to integrate minority ethnic groups into the political settlement, and indeed "Obote's declared objective of uplifting other regions and narrowing the gap between them and Buganda endeared him to many who disapproved of and envied Buganda's advantages" (Golooba-Mutebi, 2008, p. 8).

The political settlement under what would be Milton Obote's first reign in power can therefore be characterised as moving from a competitive political settlement involving a broad-based ruling coalition towards a narrower ruling coalition with dominant party/leader characteristics (Levy, 2012). As tensions developed, the policy priority given 
Investigating the links between political settlements and inclusive development in Uganda

to inclusive development arguably increased, but was expressed primarily in ethnic rather than programmatic terms, while the capacity to deliver public services in a broadbased way was diminished. Ideas around nation building and development were closely entwined with these elite-led political machinations.

\subsection{The reign of Idi Amin: 1971-1980}

After deposing Obote, the regime of Idi Amin initially pursued efforts to forge a broad coalition, which included appointing the majority of his ministers from outside the army and across the country's diverse regions, and also to placate the Baganda (GoloobaMutebi, 2008; ICG, 2012). Before long, however, the new government outlawed parliament, banned political parties, dismantled local government councils, appointed military officers as provincial governors and weakened the judiciary. The regime instigated "an era of undisguised exclusion", characterised by "extremely low levels of power sharing, evident in a striking ethno-religious bias in favour of a Nubian-Kakwa core group and Muslims in general" (Lindemann, 2010, p. 23). Amin managed to tilt the balance of power firmly southwards, but the instability inherent in this narrowly based coalition led to increased use of coercion and violence by the regime, involving the murder of prominent civilians and of army officials from Obote's ethnic group in a bid to secure his regime. ${ }^{4}$

Amin's infamous expulsion of Asians (both Ugandan and non-Ugandan) in 1972 left a damaging political as well as economic legacy. The destruction of around 90 per cent of the trading network meant that: "State officials became far more significant to the economy", and as a result, "Patronage and corruption thus became firmly entrenched at all levels of the public service", (ICG, 2012, p. 4). It also helped ensure that informal safety nets reached deep into Ugandan society, whilst also reducing the extent of formal economic productivity. ${ }^{5}$ The expulsion thus left Uganda without the presence of a largely autonomous economic interest group that did not rely entirely on state largesse to reproduce and advance itself and which could provide alternative sources of accumulation to the rents on offer in the public sector.

In development terms, per capita GDP reduced from \$254 in 1968 to a mere \$98 in 1980 (World Development Indicators). Efforts to secure fiscal sovereignty for the Central Bank were initially in vain, with Amin allegedly ordering the murder of the governor (Mazrui, 1991, p. 374). ${ }^{6}$ However, it seems that the impacts of Amin's reign on service delivery

\footnotetext{
${ }^{4}$ Most observers estimate that over 100,000 Ugandans were killed under Amin.

${ }^{5}$ Although the most dramatic instance of its type, the expulsion of Asians from Uganda revealed the constraints that African nationalist leaders perceive themselves to be under with regards to not being seen to empower non-African capitalists (see Khan, 2010, on Tanzania).

${ }^{6}$ As noted above, the establishment of a more positive synergy between fiscal and military discipline would have to wait until Museveni finally invested the Bank with autonomy and supportive macro-economic policies in the early 1990s (Tumusime-Mutebile, 2010).
} 
Investigating the links between political settlements and inclusive development in Uganda

were less pronounced than those on governance and economic development. The expansion of educational and health facilities, at least in the initial years, proceeded as quickly as under Obote, if not faster (Bukenya, 2012). Nonetheless, this expansion had no lasting effects, as eventually service delivery declined as economic crisis took its toll and large numbers of professionals fled the country, often leaving local communities to assume the state's responsibilities (Sjogren, 2007).

\subsection{The second Obote regime: 1980-1985}

Amin's "extreme minority regime" (Lindemann, 2010, p. 26) was overthrown in April 1979 by a broad coalition of forces, comprising more than 20 opposition groups and organised under the military guidance of the Tanzanian army (Golooba-Mutebi, 2008, pp. 11-12), including a group led by Yoweri Museveni. In the absence of an agreement amongst elites on basic institutional arrangements for managing power, numerous political factions, backed by their respective armed groups, continued to jostle for dominance as the country once again descended into violence and instability. The first elections after the regime overthrow were won - amidst violence, murder, obstruction, and intimidation of opponents - by the political party with the largest armed group, Obote's UPC. Many declared the elections rigged, with Museveni and other losers forming insurgent groups and opting to take up armed struggle against the northern-dominated UPC regime. Obote launched a brutal response, waging a campaign of vengeance against the Baganda and, in the West Nile region, groups that had supported Amin's rule. With Obote unable to control the military, the rule of law broke down amidst serial human rights abuses and collapse of governance (Golooba-Mutebi, 2008, p. 15).

Museveni's Popular Resistance Army (PRA, later NRA) ${ }^{7}$ soon created a liberated zone in Buganda, rallied Obote's historical enemies, the Baganda, to his side and together with his western-based Banyankole kinsmen and other allies from mainly the south of the country, led what was "universally regarded as a southern rebellion against almost unbroken northern rule" (ICG, 2012, p. 5). The NRA's struggle against the regime generated a great deal of popular support, particularly in the south, as did the NRM's apparent commitment to building consensus, the emphasis it placed on popular empowerment and development via the role of resistance councils and education, and its apparent concern for the inclusion of women and other hitherto marginalised social groups. That support served as the bedrock on which the NRM would later build alliances with many of the country's political and other elites, who had hitherto remained loyal to their original political groupings or remained relatively detached from politics. The Obote II regime held out until July 1985, when it was deposed by the short-lived military junta, which was eventually ousted by the NRA in January 1986.

\footnotetext{
${ }^{7}$ Renamed National Resistance Army (NRA) after its merger with the Yusuf Lule-led Uganda Freedom Army (UFA).
} 
Uganda's post-colonial history until 1985 thus involved ruling coalitions that were initially intended to be broad-based but which became increasingly characterised by ethnic, regional and religious exclusivity, with heavily militaristic tendencies in support of moves away from political disorder and towards a dominant leader form of political settlement. ${ }^{8}$ Part of this legacy was to ensure that the military would remain a key player within the ruling coalition. In ideational terms, the notion of Uganda as a coherent political entity and the idea that the state was a legitimate political force were both heavily damaged during this era, beyond repair even to this day in the eyes of some.

\section{The political settlement from 1986 to the present}

\subsection{The making of a broad-based dominant party political settlement}

Yoweri Museveni and his National Resistance Movement (NRM) came to power after many years of intense inter-elite conflict, characterised by a failure of elites to reach agreement over the basic institutional arrangements for the organisation and operation of political power. Museveni's rise to power marked a crucial turning point in the country's politics, particularly with his rejection of multi-party politics in favour of an "allembracing" movement political system, a system designed to avoid the sectarian conflicts associated with political party competition in Uganda and reflective of Museveni's conviction that Uganda's peasant-based society was unsuited to the practice of multi-party politics. According to Mamdani (1996), the NRM's commitment to challenging parochial political identities extended to the arena of local governance, with the local rights of citizenship redefined in terms of residence rather than ethno-territorial belonging. However, these progressive ideas around citizenship and state-building in Uganda were also driven by a strategic sense of self-interest: Museveni's own ethnoregional group lacked the demographic weight to rule without building alliances across ethnic lines, particularly regarding the dominant Baganda, with whom his NRA built a coalition during the guerrilla struggle in the Luwero Triangle.

The NRM's approach marked a significant change in the ethno-regional character of the ruling coalition, particularly in terms of the erstwhile dominance by northerners. The NRM's armed wing, the National Resistance Army, had recruited almost all of its fighters from the south, in contrast to the northern-dominated national armed forces, and the NRM's real and potential rivals were generally courted and encouraged to join or support the new government. However, an important exception here involved revenge attacks undertaken by NRA forces whilst chasing soldiers loyal to Obote back into the north,

\footnotetext{
${ }^{8}$ The militarised character of politics in Uganda was apparent during Obote's second regime, at the time his government was battling the Museveni-led insurgency, when he used to mock the leader of the opposition, Paulo Ssemogerere, across the despatch box (i.e. within a formal political institution designed to contain conflict within the confines of political debate), with the taunt of 'where are your generals?' (Golooba-Mutebi, 2009).
} 
Investigating the links between political settlements and inclusive development in Uganda

which damaged relations between the new regime and the north. Large numbers of northerners who had been part of the defeated army left for exile, whilst others launched insurgencies in the north (Acholi), northeast (Teso) and east (Samia). In this context, even when Museveni and the NRM embarked on putting together its broad coalitional government, many northerners chose not to join. According to Lindemann (2010), northerners have been systematically under-represented at the leadership level within Uganda's key political, military, and bureaucratic economic institutions since 1986. The mistreatment of northerners and their expulsion from political power ensured that although Museveni's generally broad-based coalition building and co-optation of various groups was able to secure stability across most of the country, another cycle of civil conflict was not avoided. The struggle between the Lord's Resistance Army and the Ugandan armed forces would run from 1987 until the early 2000s, and constituted the main challenge to the political settlement in the post-1986 era.

Other challenges also arose from the nature of the political settlement established by the NRM, particularly concerning the institutional arrangements for gaining political power. The first signs of discontent amongst elite actors emerged during the constitution-making process, when some began to suspect that the Movement was more interested in perpetuating its stay in power rather than genuinely seeking to create new forms of state-society relationships (e.g. Oloka-Onyango, 2000). Museveni's broad-based ruling coalition came under its first serious challenge on these grounds in the run up to the first post-war presidential elections in 1996, which saw some supporters of multi-partyism return to their parties, form new ones, or exit the political arena altogether. Tripp (2010, p. 60) captures succinctly the forces at work here:

"...in a semi-authoritarian regime, most contenders for power find that there is only one game in town. Since the possibilities of reforming the dominant power configuration are limited, their only option is to make peace with the powers that be or leave and seek other more precarious options - for example, forming or joining a new political party".

By the 2001 elections, a critical mass of defectors had emerged and coalesced round the Reform Agenda, with Kiiza Besigye as the unity candidate - a grouping that later metamorphosed into the Forum for Democratic Change (FDC). Museveni won the elections in the face of stiff opposition, helped in no small measure by a great deal of direct meddling by the military and other state agencies (Kobusingye, 2010). This continued post-2001, with the coalition continuing to suffer defections as agitation for the restoration of multi-partysm mounted. The most momentous of these exits were those of senior government and NRM figures who either resigned or were removed from both after failing to persuade President Museveni against proposing constitution amendments in 2005 to remove presidential term limits. The removal of term limits from the 
constitution took place as part of a larger process of opening up political space to allow other political parties to compete for power with the NRM, which went on to register as a political party. Museveni's about-turn to become a strong advocate of multi-party politics was mainly to shore up a ruling coalition that he felt had become too internally fractious in the absence of a political opposition (Makara et al., 2009), by precipitating the exit of dissenters. ${ }^{9}$

\subsection{Mapping the ruling coalition in Uganda}

These developments, along with indications that the President has over recent years relied increasingly heavily on a narrow coterie of followers mainly from his home region, including his own family, has led some to argue that the broad-based coalition established in the late 1980s has become much narrower in character. ${ }^{10}$ This rather hasty interpretation overlooks the character of the coalition and the strategies that Museveni employs to hold it together. This involves not only: (a) a highly top-down and nepotistic approach at the very centre; but also (b) the co-optation of elites who can secure support from a wide range of interests and factions; and (c) the direct mobilisation of a significant network of grassroots support. As such, the ruling coalition is comprised of an inner core, a wider circle that comprises both some key players and what we term here 'window-dressing elites', and then a broader, more localised network.

At the centre of power is the President himself, who has ensured that all decisionmaking powers ultimately rest with him, in what has become an increasingly presidentialised form of semi-authoritarian democracy (Tripp, 2010). ${ }^{11}$ Amongst the few people able to influence him directly are his immediate family, some of whom hold influential positions themselves, including his son, Lt. Colonel Muhoozi Kainerugaba (Head of Special Forces), his brother, General Caleb Akandwanaho (aka Salim Saleh, who is a Presidential Advisor on Security), and his wife, Janet Kataaha (Minister of State for Karamoja Affairs). This coterie also helps the President to reach specific groups, including (and respectively) young officers in the military; the president's personal grassroots political network; and evangelical churches, women's groups, and the Karamoja. This inner circle also includes Amama Mbabazi, the Prime Minister and NRM Secretary-General, and some leading army figures. Less well-known personalities, who also lack a popular constituency but who are perceived as critical for executing government business, are employed within State House, the Office of the President, with others operating from beyond formal state structures.

\footnotetext{
${ }^{9}$ The exact vernacular (Luganda) phrase he used was "tubejjeko" (let us reject - or eject - them).

${ }_{11}^{10}$ See, for example: Rubongoya (2007); Tripp (2010).

${ }^{11}$ One source from the business community referred to Museveni as having "an emperor's mentality" (interview with one of authors, 3 March 2012).
} 
Beyond this, but still within a broader inner circle, there are regional political barons, who act as his local lynchpins in their areas of origin. Some still serve in positions of power and authority, while others have held senior governmental or military positions at some stage. They are critical in cultivating and building local support and delivering votes for him and for the NRM. A good example is Hajji Hassan Basajjabalaba, the chairman of the NRM's business league and a controversial business figure, whose role has included forging links with the business and Muslim communities. In addition, he is an influential personality in his home region of Bushenyi, arguably the most politically volatile region in western Uganda. ${ }^{12}$

There is also a further layer here, what might be termed the 'outer circle', which consists of 'window-dressing elites'. Carefully selected on the basis of region, area of origin, and religious background, Museveni appoints them to prominent positions, so that their constituencies can see that they are represented at the highest levels of government - a strategy that helps explain Uganda's very large Cabinet. Despite their lack of real influence, this enables the President to keep important constituencies on side and to maintain the veneer of inclusivity. The non-core elites with membership in Museveni's political coalition or who service it in different ways are also to be found outside mainstream politics. Some are in manufacturing industry, import and export trading, farming and also in other spheres of life, including organised religion and even in traditional medicine and fortune telling.

\subsection{State-business relations within the ruling coalition}

Having initially espoused a preference for socialism over free market economics, Museveni's NRM did not immediately endear themselves to the very small business community in Uganda. However, having pragmatically adopted IMF measures from 1987 onwards (Mugyenyi, 1991; Ochieng, 1991), the NRM soon embraced the private sector as 'the engine of economic growth' (Hansen and Twaddle, 1991, Nyilinkindi and Opagi, 2010) and have been unrelenting in their promotion of business and non-interference with private ownership of property ever since. Efforts to encourage the return of members of the Ugandan-Asian business community, and to return property to them, helped establish and concretise the NRM's alliance with them, in addition to attracting investment and contributing to the rebuilding and expansion of the private sector.

Another avenue through which the government has built and strengthened its alliance with the business community is the privatisation of state-owned enterprises. The process started in 1993 and by 2008 had seen most of the public enterprises privatised or liquidated and their assets sold off. Significantly, many of the enterprises were auctioned

\footnotetext{
${ }^{12}$ As such, he has been able to deliver some votes to the President and the NRM once former NRM heavy weights from the region left the party or became perceived as less reliable (e.g. Kahinda Otafiire). We return to the important issue of state-business relations below.
} 
off to individuals with connections in high places, including senior politicians and army officers (Mwenda and Tangri, 2005; Tripp, 2010).

The embedding of these two groups into the business community further widened and deepened the NRM's reach within it, as they developed close relations with other members of the community. These relationships have usually been described as collusive rather than productive. For the most part they are not based on the state picking and nurturing winners, as occurred during the development phase of East Asian capitalism, but rather on politicians and members of the business community forging alliances in pursuit of individual interests (Mwenda and Tangri, 2005). Asian members of the business community are amongst the largest donors to the NRM for its political activities, especially around election time. ${ }^{13}$

Finally, there is a perception among members of the indigenous business class that the government cares more about the concerns of foreign investors and 'big business' than their own. ${ }^{14}$ These perceptions have divided the business community and reduced incentives for engaging in collective action that might influence the conduct of the state for the more general good. Some of the close state-business relationships that have developed have spawned complex and largely hidden webs of financial and business relationships, from which some politicians derive money to fund their political campaigns and the NRM's political activities (Mwenda and Tangri, 2005). Some of the webs link members of the business community who seek favours of one or other kind directly to State House. Involved in these networks are both local, mainly large capitalists, including Asians, and foreign investors, including multi-nationals or their representatives. The multi-nationals are sucked in by their search for opportunities for different kinds of contracts to do business with the state, the largest consumer of goods and services in the country. According to one respondent, "they leverage their influence with the state to make money". ${ }^{15}$ As of now, perhaps the most committed members of the coalition are among foreign investors, especially the Chinese and newly arrived Indians and Pakistanis.

\subsection{Rent-sharing at the local level}

Museveni's final and critical strategy for holding the ruling coalition together involves mobilising the grassroots, whereby he either deploys trusted and dependable aides or goes personally to talk to people about what he is doing or planning to do for them. Museveni's 'meet the people' tactics usually entail the dispensing of cash and goods or

\footnotetext{
13 Interview, 3 March 2012.

${ }_{15}^{14}$ See, for example, Mubangizi (2011); also Talemwa (2010).

${ }^{15}$ Interview, 3 March 2012.
} 
promising assistance, sometimes of a very personal kind. ${ }^{16}$ Local politicians operating at local government level, members of all types of local associations and civic groups, teachers, and notable local personalities with influence are what he refers to as $\square$ my people". ${ }^{17}$ Some are in turn encouraged by him and the party machinery to stand for elective offices, especially where incumbents have defied party discipline. These people, whose overriding desire, as a respondent put it, is "to shake the president's hand or be seen to be known personally by him and, if they win parliamentary seats, to be appointed to some position", are the base on which the Museveni regime rests today.

By forging direct relationships with the grassroots, Museveni makes it difficult for his ethno-regional barons to develop independent constituencies beyond his influence that that might interfere with his ability to mediate directly with voters. This weakening of elites enables him to appoint and maintain them in positions at his discretion, and helps explain their frequent dismissal and re-appointment. This strategy has significant electoral implications and was largely responsible for the massive entry into the NRM during the presidential campaigns in 2010/11 of people in places such as northern Uganda, who had previously supported opposition parties. NRM mobilisation was particularly impressive around the 2010 NRM primaries, which allegedly involved more people voting than the 2011 elections themselves, and gave the incumbent a significant advantage in terms of local-level mobilisation and also the ability to manipulate voter registration processes. A further consequence of Museveni's populist approach to rentsharing and building constituencies at the local level, along with his mistrust of autonomous sources of power and lack of interest in institution-building, has been that Uganda has moved relatively swiftly from being a 'dominant party' form of political settlement to a 'dominant leader' approach. Museveni's preference for a mixture of autocratic decision-making and populist appeals to/mobilising of the grassroots has hollowed out the Movement of any real decision-making powers or organisational basis. $^{18}$

\footnotetext{
${ }^{16}$ It is not unusual for, instance, for the President to pay the medical bills of some person in a remote village whom he encountered at a public rally or in the private home of a prominent local supporter, gestures that tend to engender great feelings of gratitude and loyalty.

${ }^{17}$ For example, it is these people whom he used to out-smart his opponents within the NRM during the debate and eventual decision to endorse the lifting of limits on presidential terms in office. While the high-level elites were debating the matter in Kampala, he and his agents were busy in the countryside consulting and rallying support for the idea. And then 'the people' were bussed in to vote accordingly. It is the same people who are rallied to canvass support for his presidential bids in house-to-house campaigns popularly dubbed "kakuyege" (termite style). Reference to termites is intended to capture the low-key, almost clandestine approach the campaigners use. Interview (28 February 2012).

${ }^{18}$ More recent research also shows how informal groups in urban areas have used electoral competition to drive bargains with the President in ways that secure votes for the regime from previously oppositional areas, whilst further undermining formal governance institutions (Goodfellow and Titeca, 2012). Decentralisation has been critical to extending the reach of the coalition into rural areas, and has recently been extended through districtisation and the appointment of Deputy RDCs.
} 
Investigating the links between political settlements and inclusive development in Uganda

\subsection{A fragile coalition?}

"The power of lower level factions, excluded factions and opposing factions within the NRM against the president seems to be increasing, rendering the ruling coalition less stable and increasing the costs of holding the ruling coalition together" (Kjaer and Katusiimeh, 2012, p. 2).

Overall, then, Uganda's political settlement can be defined in terms of being a dominant party/dominant leader settlement, albeit one characterised by increasingly competitive tendencies. This settlement has proved to be largely successful at delivering political stability and securing impressive levels of economic governance and growth. It has also taken government closer to the people and, through largely populist measures linked to election campaigns, has also improved the access of many citizens to social services. Universal Primary Education (UPE) has been notable for its coverage of large numbers of children who would otherwise have been excluded, while the abolition of user-fees has removed the burden of paying for services wherever and whenever they are available. ${ }^{19}$ Indeed, the return of multi-party politics has deepened the populist logic of Museveni's ruling coalition. According to Kjær and Therkildsen (2012), elections have been won through the ruling elite employing a dual strategy where,

"... on the one hand, they seek support from lower cadres who are in touch with and can mobilize voters, and on the other hand by relying on policies that appeal to many voters on the short term, such as universal education programs or the Prosperity for All pledge launched in relation to the 2006 elections".

Public organisations continue to operate along largely personalised rather than impersonalised lines, although there are some contradictory trends here: for example, the electoral process itself has been greatly improved of late, but this did not prevent the campaign process from being heavily commodified, with huge financial sums (including public money) used to persuade voters (Izama, 2011). Uganda's few pockets of bureaucratic efficiency appear to have been eroded in recent years, as with the declining capacity of economic governance institutions to resist populist policy measures, supplementary budgets and macroeconomic instability. These trends appear to have worsened with the return of multi-party democracy, as has the apparent reluctance to punish those political barons found to have been involved in high-level corruption cases, but on whom the regime appears to depend with regards to generating votes. As such, and although dominant ruler political settlements are sometimes thought more likely to enable the top-down enforcement of effective and accountable forms of governance, including in-service delivery (Levy, 2012), there is growing evidence in recent years that

\footnotetext{
${ }^{19}$ In a sense, the abolition of user-fees makes a mockery of the idea of free services, as for the most part the health system in Uganda is unable to provide even the most basic of services, as research over the years has shown (Neema, 1994; Twinomugisha, 2004; Golooba-Mutebi, 2005).
} 
the progressive possibilities of the current set of power arrangements has been heavily undermined. This is both because of dynamics internal to the ruling coalition, which have rendered it less developmental in outlook and function, and because some of these gains have turned out to be less progressive than they first appeared (e.g. the issue of quality with UPE; see Section 7). Key dynamics include the rising costs of the system, or 'inflationary patronage' (Barkan, 2011), which has been further extended under the pressures of maintaining power under multi-party competition.

There is also some evidence that the political settlement has become more fractious of late, both at the centre and in terms of elite-mass relations. At the centre, a new generation of parliamentarians - made up of opposition members, but also independents and some critical NRM supporters - are increasingly standing up to the executive over critical issues such as oil and high-level corruption. Popular support for the regime may also be waning, despite the 2011 election results. Qualitative research with voters immediately after the 2011 elections revealed that many voted for the Movement out of fear of what the regime would do if it lost, whilst also calibrating their Movement-vote to send a message to the government regarding the poor performance of incumbents (Golooba-Mutebi, 2011). The period following the election, also characterised by economic difficulties, witnessed unprecedented levels of popular protest from several different social groupings, as with strikes and walk-to-work protests. The latest Afrobarometer results revealed high levels of discontent regarding the country's direction of travel and record on the economy, jobs and inequality. This sense of disenchantment is also reflected in the participatory research undertaken for the 2012 Poverty Status Report (MFPED, 2012). A further point of fracture over recent years has involved the souring of relationships between the NRM and the Buganda monarchy and monarchists over a range of issues, including Baganda demands for federalism, the return of properties expropriated by the 1960s Obote government, land reform proposals, and the perceived mistreatment of the King by, for example, interfering with his freedom of movement and turning some parts of his kingdom into autonomous cultural areas with their own cultural leaders (Tripp, 2010).

However, the political capacity of Museveni to hold the current coalition together should not be under-estimated. His skills at doing so were particularly apparent in the run-up to the 2011 elections, which many astute observers had predicted he would lose, where he persuaded far larger numbers of politicians to defect from the opposition to the NRM than crossed from the NRM to the opposition. Unless opposition parties organise and market themselves better, and in particular, a leader emerges who is able to command respect and votes at the local level, this pattern looks set to repeat itself in future years, and as some have already noted, "access to massive oil revenues could solidify Museveni's hold on power" (Kathman and Shannon, 2011, p. 28). 
Investigating the links between political settlements and inclusive development in Uganda

\section{Implications for state capacity, elite commitment and inclusive development}

\subsection{Achieving structural transformation in Uganda}

There is little evidence to suggest that Uganda's political settlement is conducive to achieving structural transformation, particularly in terms of fostering the types of state capacity required to achieve this. Research on 'developmental states' suggests that in addition to maintaining political and macroeconomic stability, this also requires both synergistic relationships with productive capitalists (Evans, 1995) and the capacity to discipline capital in line with the national interest (Khan, 2005); the capacity to restructure property rights for growth (e.g. prioritise the allocation of public land, carrying our pro-poor land reform); and to assist in technology acquisition (e.g. through prioritised infrastructure support; see Gore, 2000; Khan, 2005).

Our analysis suggests that with the exception of maintaining political and macroeconomic stability, Uganda largely lacks the other capacities identified here, and that even here there are question marks. The case of macroeconomic stability is particularly revealing of the interplay between the political settlement, ideas and transnational actors in Uganda over time, and how this shapes capacity and commitment to deliver. The very creation of the Central Bank of Uganda in 1966 coincided with the onset of constitutional crisis and eventual armed conflict between the regime and forces loyal to the Baganda monarch, setting in play what Mazrui $(1991$, p. 374) referred to as "The dialectic between militarized politics and structural adjustment through fiscal adjustment". Efforts by the first governor to secure fiscal sovereignty for the Bank were ultimately in vain, with Amin allegedly ordering his murder (op. cit.). The establishment of a more positive synergy between fiscal and military discipline would have to wait until Museveni finally invested the Bank with autonomy and supportive macro-economic policies in the early 1990s (Tumusime-Mutebile, 2010). Indeed, it is suggested that Museveni only bought into the idea of maintaining macroeconomic stability vis-à-vis a mixture of ambitious expenditure plans and public sector profligacy when he came to understand economic governance in terms of military discipline (op. cit.). This commitment was also heavily influenced by the need to retain good relations with the IFls during the lengthy period through which Uganda was both heavily indebted and aid dependent. As reported by Mosley (2012), President Museveni was persuaded by the Governor of the Bank of Uganda to effectively hand over the reins of economic governance to him, thus enabling the Governor to take a lead role in handling donors and building up a cadre of highly competent public servants securing in the key economic institutions. In many ways, the Governor personified the 'embedded autonomy' (Evans, 1995) required for states to perform developmental functions, in that he maintained close relations with the executive while keeping key economic institutions largely free from external political pressure. Given its strategic importance, the regime remained happy to allow (if not actively promote) economic governance institutions to 
function as 'islands of effectiveness', particularly within MFPED and BoU, in ways that were not apparent in other areas of public service.

The question now is whether this commitment remains, now that both the political and political economy of development has changed in Uganda. Relevant shifts here include the return to multi-party politics, the declining dependence on aid and additional resources generated through the newfound oil and growing investment from new economic partners (especially China), ${ }^{20}$ and new geopolitical imperatives resulting from Uganda's involvement in Somalia and security concerns over the advent of South Sudan. For example, the deepening of competitive tendencies within the Ugandan polity following the return to multi-party politics in 2005, and the decision by Museveni to commercialise/buy rather than enforce victory at the 2011 elections (Izama, 2011), seems to have led the regime to become more relaxed about macroeconomic stability, which was compromised by very high rates of public expenditure over 2010-12. Although economic factors are important here (Section 2), the problems of high inflation and limited growth seem to have been driven in part by the lack of fiscal discipline around the 2011 elections, particularly in terms of the use of supplementary budgets to cover high levels of unscheduled expenditure on campaign costs and military hardware (Izama, 2011), the latter being eventually justified with reference to regional security concerns. In a context of increased electoral pressures, 'competitive clientelism' requires an increasingly expensive patronage machine to maintain the regime in power (Barkan, 2011). This raises concerns that the regime will be increasingly willing to compromise on short/medium-term macroeconomic stability targets, and that the 2016 elections may see Uganda increasingly resemble countries like Ghana, where macroeconomic discipline tends to be cast aside during elections. ${ }^{21}$

In terms of restructuring property rights for growth, the government has generally failed to ensure that one of Uganda's most significant assets, namely its highly productive and fertile land, is distributed in ways that maximise returns on investments. This failure to

\footnotetext{
${ }^{20}$ This tension is apparent in the government's policy discussions, which have become somewhat divided between the 'new productivists' and the neoliberal old guard (see below).

21 Those associated with the high-performing institutions of economic governance have expressed concern: for example, the IMF initially refused to award Uganda its stamp of approval in 2011-12 concerning the Policy Support Instrument, and the World Bank Uganda's Senior Economist stated publicly that the "continued use of supplementary budgets is affecting budget credibility and started to raise questions about the degree of fiscal control by authorities." The Governor of the Bank of Uganda himself gave an interview to the UK-based Financial Times during the summer of 2011 bemoaning the level of political interference in the economy. Initially, the mini-economic crisis enabled the Bank of Uganda to re-assert its technocratic credentials, as it imposed strict monetary tightening measures over 2011-12, most notably through high interest rates, which proved successful in terms of reducing inflation to within single digits from a high of 30 per cent in 2011, albeit with costs in terms of growth and productivity. However, the fact that the President's support was required in March 2012 to ensure the Governor escaped censure in parliament for his role in a political corruption scandal suggests that the autonomy of this pillar of economic governance may have been further compromised.
} 
persist with and implement land reform reflects in part the nature of the ruling coalition and in particular the fractious relationship between the regime and the Baganda. More broadly, when the President has sought to intervene directly, as when trying to appropriate land for larger capitalists to develop (e.g. as sugar plantations in the north), he has often been unable or unwilling to face down the groundswell of local protest against such moves, indicating that the current political settlement or 'social contract' between state and society in Uganda, as elsewhere in Africa (Nugent, 2010), does not yet stretch to allowing the state to restructure power relations around land. This reflects a broader problem whereby most Ugandans do not perceive that the regime's efforts to reform land tenure systems or implement other legislation around land is being undertaken in the national interest, rather than his own or that of elites around him. As suggested by recent thinking on state capacity (vom Hau, 2012), legitimacy is a key mediating factor, which can either enable or disable government action.

Importantly, the agricultural modernisation required to push forward structural transformation in Uganda is highly unlikely to occur, given both the meagre size of the budget allocation for this area (which at around four per cent of the budget is less than half of that recommended by the Maputo Agreement), the high degree of politicisation of policy-making and delivery in this area (Kjaer and Muhumuza, 2009) and the state's (related) lack of institutional capacity to deliver integrated and effective forms of agricultural policy. The policy responses on employment generation to date have been piecemeal, focused on training and low-level incentives, rather than more strategic interventions.

The capacity of governments in Africa to not only 'pick winners' but also, and more importantly, discipline losers, is a key difference between the limited development progress that the continent has experienced in comparison to East Asia. Uganda reflects this general scenario, as evidenced in Museveni's periodic efforts to identify winners, from the Strategic Exports Initiative of the early 2000s (e.g., Hickey, 2005), through to these efforts to secure land for particular companies to establish sugar plantations. As an IMF report notes, "In recent years, tax breaks and/or government financial support have been provided to activities as varied as the hotel and tourism sector, hides and skins, textiles, palm oil production, micro-finance etc." (Selassie, 2008, p. 37), few with any lasting success and nearly always accompanied by suspicions that the benefits have been mainly garnered by NRM loyalists.

As such, the government of Uganda clearly lacks the capacities usually associated with achieving the ambitious goal of structural transformation. A further bottleneck concerns the limited institutional power and intellectual capabilities that lie behind the structural transformation agenda in Uganda, whereby the 'new productivists' (Hickey, 2012b) currently lack the political weight and analytical capacities to make and win the intellectual and strategic case for higher investments (e.g., one that carefully addresses 
macroeconomic concerns over the medium to long term through a strategic sequencing of high-return investments and carefully managed portfolio of blended loans and grants) that could overturn the institutional and ideological power of the neoliberal tendency and its dominant commitment to macroeconomic stability. This struggle could be usefully engaged in by external actors by catalysing intellectual exchanges and introducing new thinking on how to achieve structural transformation within key policy circles, a brokerage function (Booth, 2011) that certain donors would be well-placed to contribute towards. In general, though, it will not be easy to overcome the capacity gaps identified here. Uganda's ideological shift to a largely market-oriented approach in the late 1980s and 1990s involved privatising most public utilities and reducing the government's role in the economy. Having failed to adopt the developmental state structures associated with fast-transforming states, building them now will require a degree of effort and discipline that is at odds with the country's trajectory regarding the incentives that prevail within the ruling coalition.

\subsection{Service delivery}

The government's approach to delivering public services can also be related to the incentives that flow from the prevailing political settlement, although a series of other factors also seem to intervene here. For example, both health and education have been beneficiaries of large-scale investment scheduled according to the electoral calendar, as with the introduction of UPE in 1996 and Universal Secondary Education in 2006, and abolition of user fees in health in 2001. This is in line both with the NRM's early commitment to promoting development and the increasing pressure faced by the government to use it to help maintain itself in power. This has had significant benefits, including significant improvements in female enrolment, and recurrent expenditures in these remain very high, despite a relative turn away from social sector spending in recent years towards investments in infrastructure. However, the government's poor record on delivering services in effective and accountable ways raises questions about the extent to which these were populist giveaways, designed primarily to maintain the dominant party/leader in power, or reflective of a more deep-seated commitment to delivering high-quality public services over a prolonged period. More specifically, and amidst growing calls for the government to shift the focus from the level to the quality of provision (e.g. World Bank, 2012), it appears that even if the executive is committed to delivering high-quality services, it lacks the ability to develop the required levels of capacity and compliance within the civil service to achieve this, as illustrated by the cases of health and education.

In terms of health, the government has made major investments, building hundreds of new health units, scaling up immunisation, and boosting the health budget 
Investigating the links between political settlements and inclusive development in Uganda

considerably. ${ }^{22}$ However, the quality of service delivery remains low, with large budgetary allocations to the sector having a minimal impact on front-line services. At one level, this reflects the fact that Uganda's health sector suffers from a range of problems, including staff absenteeism, a shortage of drugs and supplies, corruption, weak accountability, professional misconduct, poor management, and lack of human and financial resources. However, the systemic nature of these problems reflects the broader problems discussed here, whereby the clientelistic political settlement establishes an incentive structure in the public sector that is inimical to the development of efficient and accountable institutions capable of delivering services on an impersonal and universal basis. $^{23}$

This has been particularly apparent in the health service, which has suffered from highlevel corruption scandals involving successive health ministers, most famously around the global health fund. Levels of accountability are generally poor (Wild and Domingo, 2010), particularly in relation to financial management and general documentation, where the problems of corruption and low capacity are firmly entwined. The President's decision to establish the Medicines and Health Services Delivery Monitoring Unit under State House rather than within the health ministry reflected a growing sense of frustration with the bureaucracy and a lack of will to tackle these problems at root. It also reflects a broader tendency in clientelistic political settlements to undermine or bypass formal institutions in favour of more personalised and discretionary ones.

Similar dynamics are at play in the education sector, where high levels of investment have also reaped some important dividends, including high levels of enrolment and widespread improvements in the development of school infrastructure. However, funding remains inadequate when compared to demand and the disbursement of resources is often subject to long delays. Financial and other management problems include alleged inflated funds, ghost teachers and schools, and incomplete and shoddy construction (Ahimbisibwe, 2012). Accountability in UPE schools is an enormous challenge, with the mismanagement of resources, shoddy work by contractors and teacher absenteeism all widespread and largely unpunished. The outcomes in terms of quality are striking: according to a 2011 report by Uwezo, a local research firm, nine out of every 10 children in year 3 of primary school could not read and understand an English story meant for pupils in year $2 .^{24}$

For some, this problem reflects the way that UPE is resourced and delivered, whereby financing comes primarily from donors, rather than domestic taxation, and the parent and teacher associations which previously supported and monitored schools have been

${ }^{22}$ For example, between 2005 and 2009 the health budget was tripled from UGX240 billion (USD120 million) to UGX734.67 billion (USD367.33 million).

${ }_{23}$ Annual Report, Medicines and Health Service Delivery Monitoring Unit, 2010.

${ }^{24}$ Kalinaki, K. D., 2012. 'Parents can save ailing UPE if they meddle more, cough up some money'. Daily Monitor, 23 February. 
Investigating the links between political settlements and inclusive development in Uganda

undermined in favour of empowered head teachers who report directly to government, leading to a significant reduction of local accountability and ownership (e.g. Dauda, 2004). It is also possible to identify a downward spiral here, whereby reduced quality and ownership have led less-poor families to withdraw their children, thus deepening the vicious cycle whereby 'services for the poor tend to result in poor services'.

\subsection{Revenue collection}

The issue of revenue collection is important, not only in terms of providing the resources required for governments to promote development, but also because it reflects the capacity of the state to extract revenue in legitimate ways from its population, the broader character of the settlement between state and citizens, and helps illustrate the possibilities of more effective and accountable forms of governance (Brautigam et al., 2008). Uganda's performance in terms of revenue collection has been significantly below the Sub-Saharan African average, with a tax-take of around 12.5 per cent compared to 27 per cent more broadly. Although some reforms have been undertaken in this area, key challenges nevertheless remain, including a narrow tax base, a large informal sector that is outside of the tax net, lack of reliable data, and limited human capacity for supervision (ibid: 120).

The URA was once heralded as one of Uganda's few pockets of bureaucratic excellence, shielded from overt political influence and the beneficiary of large-scale donor funding (Robinson, 2006). This reputation had diminished by the early 2000s, and while some observers have suggested that the current leadership has largely turned things around again, Uganda's IGG 2008 National Integrity Survey showed that 77 per cent of households rated the URA as corrupt. The case of URA reflects how difficult it has proven to build and maintain 'pockets of bureaucratic excellence' within Uganda's public sector in light of strong political pressures on them to perform other roles demanded by the politics of patronage. Widespread corruption tends to further undermine the capacity of the state in the overall management of available resources in the interest of poverty reduction. Together, these challenges mean that Uganda does not have adequate and equitable tax-raising procedures.

\subsection{Oil and the politics of development}

In 2006 Uganda discovered major deposits of oil and gas, with oil levels estimated at 2.5 billion barrels. Although it is unlikely to start flowing until around 2017-18, at current prices, and if oil is extracted at its estimated peak of over 100,000 barrels per day, "revenues are likely to be in the order of US $\$ 2$ billion per year (around 12 per cent of GDP)" (Vokes, 2012, p. 1). Therefore the discovery of significant quantities of oil has already altered the political economy of development in Uganda. 
One study has found that major investments of oil wealth in Uganda's agricultural, health and education sectors would all help mitigate the worst effects of Dutch Disease while also promoting poverty reduction and productivity (Bategeka and Matovu, 2011). However, the main presidential priority seems to be to invest proceeds from oil in infrastructure, which is likely to have more ambiguous effects: on the one hand it offers critical public goods that can be exploited by other sectors as well as oil, whilst also tending to drive up the exchange rate, on the other. Thinking in terms of Dutch Disease also needs to go further to identify the deeper political economy of state-business relations that tends to emerge in oil economies, whereby those firms exporting garments, manufactured goods, agricultural products, tourism, and processed items become marginalised through the rent-seeking behaviour of firms involved in natural resource extraction, which often encourage high-cost infrastructure (e.g., by monopolising power or ports; see Pritchett and Werker, 2012). The extent to which Uganda will benefit from oil wealth also depends on the capacity of the state to both agree Production Sharing Agreements with oil companies that protect the national interest and extract tax revenue from them, with high-profile disputes over both suggesting that this is at best in the balance.

Oil revenues are closely associated with an increase in rent seeking and a decline in political accountability, with the deepening role of transnational oil corporations tending to reshape governance priorities in ways that are potentially detrimental. ${ }^{25}$ History suggests that countries will be better placed to avoid the more damaging implications of oil wealth, where certain forms of not only institutions but also politics are already in place, including an inclusive ruling coalition that is generally committed to ruling in the national interest, ${ }^{26}$ strong and accountable institutions, ${ }^{27}$ and coherent and effective regulatory policies. These are in descending order of importance, given the extent to which institutions are allowed to function and policies become implemented is a function of the underlying political settlement (Poteete, 2009). In Uganda the process of establishing three-part legislation on the exploration, production, licensing and revenue

\footnotetext{
25 "Analysing 50 years of data for 170 countries in all regions of the world, it finds little evidence for some of the more dire claims made by earlier studies: that extracting oil leads to abnormally slow economic growth, or makes governments weaker, or more corrupt, or less effective" (Ross, 2012 , p. 7). Nonetheless, the same study shows that "...oil tends to both keep authoritarian regimes in power, and undermine low-income democracies; that oil revenues fail to trigger democratizing pressures, in part, because of their secrecy; that authoritarian leaders are paradoxically more eager than democratic ones to keep domestic fuel prices low; and that oil has only had anti-democratic effects since the upheaval of the 1970s." (Ross, 2012, pp. 16-7).

${ }^{26}$ Poteete (2009) has argued that the only country in Africa to successfully avoid the resource curse, Botswana, did so as a result of the character of its ruling political coalition, which she describes as inclusive (and ruling in the national interest), and also stable: "In countries with stable political coalitions, however, politicians face fewer doubts about simply staying in power and are less tempted to squander natural resource earnings on rentier politics." (Poteete, 2009, p. 549)

${ }^{27}$ According to one source, the resource curse is not inevitable, "but very strong institutions of economic governance required to overcome this" (Collier, 2011, p. 12).
} 
management of oil is underway: as of April 2012, the first two were with parliament, while the final one on revenue management was still with Cabinet. The revenue management plans appear to broadly conform to international best practices, and key policy actors (MFPED, BoU and IMF) have expressed broad satisfaction with the legislation in principle. However, most observers doubt that these policies will actually be implemented and allowed to function as intended.

As things stand, Uganda's political settlement appears to be inimical to the prospect of oil wealth being exploited in the national interest. The President and his increasingly exclusionist inner circle has so far kept a close grip on oil exploitation, with the President personally supervising the PSA process and promoting a close supporter as Minister of Energy (Vokes, 2012, p. 7). ${ }^{28}$ The process of getting ready to exploit the oil has already created plenty of opportunities to appropriate rents (e.g. negotiations around PSAs, capital gains taxation, infrastructure-related investments, etc.), and lucrative security contracts around oil installations have been handed to a company associated with the President's brother, while his son commands the special forces group overseeing security in oil exploration areas. This has led to the militarisation of oil-holding regions and is in line with army's significant holding power within the ruling coalition. ${ }^{29}$

However, there are also signs that oil wealth and the government's current handling of it are leading to the emergence of a degree of countervailing power in Uganda, with some MPs and civil society activists offering a vocal and persistent challenge. The Parliamentary Forum on Oil and its mobilisation of the new post-2011 crop of largely NRM MPs, in particular, has proved to be a persistent thorn in the government's side, suggesting that a challenge to the current ruling coalition is more likely to come from within than from 'excluded' elites (see Parks and Cole, 2010). Finally, it is also plausible that oil wealth could lead to violent conflict, emanating from: (a) increased local tensions over access to land and oil resources in oil-holding regions; (b) deepening unemployment and economic problems amidst growing wealth of a few; and/or (c) disagreements over borders and ownership of (trans-border) oil deposits with DRC.

\footnotetext{
${ }^{28}$ The recent move by the government to reinstate the controversial Clause Nine within the Petroleum (Exploration, Development and Production) Bill 2012, which accords the minister farreaching decision-making powers over that of the more autonomous agencies such as the proposed Petroleum Authority, is a case in point (Daily Monitor, 11 October, 2012).

29 "For example, in early 2009 the Ugandan Army (UPDF) announced that work had begun on a new military base at Kyangwali Sub-county, Hoima District. When complete, it will be one of the largest military installations in the country - and in late 2011 it emerged that over 3,000 residents from seven surrounding villages are to be evicted, to make way for it. Yet the sheer scale of the base also fed a growing suspicion that Museveni might be using the Congolese threat as a 'cover' for establishing direct control over the oilfields themselves, through the military." (Vokes, 2012, p. 8). However, there are also reasonable grounds for security concerns around oil installations, especially close to the DRC border.
} 
Investigating the links between political settlements and inclusive development in Uganda

Overall, then, the initial signs are that oil is tending to reflect and further deepen the main political modus operandi of the leading faction in the ruling coalition: secretive, nepotistic and presidentialised rule alongside strong military involvement. The legislation currently being processed around oil revenue management may be technically optimal, but few are confident that it will be fully implemented against this political backdrop. However, these problems also seem to have catalysed a degree of countervailing power, both within parliament and amongst some civil society activists who have constructed an active debate around avoiding the 'resource curse' (e.g. Tumushabe, 2011).

\subsection{The politics of challenging exclusion and inequality (I): women}

"There is an unprecedented number of women in the National Resistance Council...and several in Cabinet...Investing in women's involvement and mobilization has enormous political and economic capital that NRM is deliberately cultivating" (Mugenyi, 1991, p. 74).

Women were identified as a significant constituency for the National Resistance Movement during the guerrilla war and in the immediate period thereafter. One of the most significant elements of Legal Notice No.1, passed in 1986 to amend the 1967 Constitution, was the inclusion of women members of the National Resistance council the equivalent of parliament - and the establishment of reserved seats for women throughout the local government system of Resistance Councils. For some observers at the time, this went beyond mere window-dressing and established women as "a real female force" (Njuba, 1991, 212). Some critics noted that: "Women were not provided with an organisation, but instead one position on each resistance committee was reserved for a woman" (Kasfir, 1991, p. 272), which might be taken as a move to individuate and weaken this potentially influential force. However, most observers accept that: "this was clearly a policy intended to create a 'critical mass' of women in key spaces...and is one promoted and closely overseen by the President himself" (Pankhurst, 2002, p. 125). In terms of political participation, the quota system, which also accords reserved seats for youth, workers, the army and people with disabilities, ensures that a third of all parliamentarians should be female (the current proportion stands at around 28 per cent), and that elected tiers of local government are also 30 per cent constituted by women. One of the few benefits of the recent policy of rapidly extending the number of districts might be said to be the corresponding increase in female parliamentarians.

However, despite early signs that the women's movement in Uganda seemed capable of transcending and challenging neopatrimonial political practices(Tripp, 2001), the movement's energies and unity appear to have been eroded by the character of patronage in Uganda, whereby women's representatives feel unable to challenge those who have given them their foothold in power (Goetz and Hassim, 2003). Although it is 
not fair to burden women alone with the task of securing gender equity - particularly given the constraints that they have faced in terms of operating within Uganda's political system (Pankhurst, 2002, pp. 125-126) - this might in part help to explain why women in Uganda still face such high levels of inequality and discrimination. Policy reforms that might benefit women and girls - other than those that fit within prevailing political incentives, such as increased primary school enrolment - have faced persistent opposition and blockages, particularly around domestic relations and issues of coownership around land (Hunt, 2004). Part of the problem here is that female political representatives in Uganda have, since the start of NRM rule, derived mainly from 'middle-class' backgrounds, rather than being more representative of the majority of Ugandans, i.e. the peasantry (Kasfir, 1991). As such they have proved less inclined to protect and promote the interests of lower-class women, in part because their relative wealth enables them to avoid relying on the same forms of state provision that poorer women require. However, it is also notable that problems of gender injustice that cutacross class divides (e.g. around domestic violence and land rights) have also been sidelined.

In many ways, the trajectory of women's political participation and empowerment in Uganda follows that of the country more broadly, whereby the initial settlement established by the NRM proceeded to make good, at least to some extent, on the new government's promise of ensuring that all citizens would be entitled to both the status and the multiple rights and goods associated with citizenship, but which has, since around 2000, been steadily eroded and in some ways been reversed. This raises significant questions concerning the links between political settlements and women's empowerment over time, and around which ideas and incentives dominate within particular ruling coalitions.

\subsection{The politics of challenging exclusion and inequality (II): the north}

As noted in Section 3, the particular forms that state formation and capitalism have taken in Uganda have involved successive efforts to incorporate the north into dominant formations, "from the Turco-Egyptian empire of the nineteenth century, through the British demarcation of the north as a labour reserve and the more recent civil war between the Lord's Resistance Army and Government forces" (from Hickey, 2009; also see Atkinson, 1994; Leopold, 2005; Southall, 1998). Since the NRM came to power in 1986, there is evidence that northerners have been excluded from influential positions within the ruling coalition, particularly regarding the higher echelons of the executive, military and also parastatals (Lindemann, 2010). At the local level, the UPDF was the main institution of government that northerners encountered during the conflict between the government and LRA. The often brutal and predatory role played by the army, involving land grabbing, internment and forced displacement, led to a strong sense amongst northerners that they were being punished for their role in supporting Obote and also failing to halt LRA atrocities (Branch, 2005; Finnstrom, 2003). In return, the 
north persistently voted against the regime and President Museveni in elections. The government's failure to include the north within its political project of rebuilding statesociety relations and the associated outbreak of conflict thus entailed the north's exclusion from the major developmental advances made during the first two decades of NRM rule, other than through the donor-funded and problematic Northern Uganda Social Action Fund (Golooba-Mutebi and Hickey, 2010). This helped foster a strong sense that the north was effectively excluded from the broader political settlement in Uganda.

This dynamic appears to have changed since around 2006, which marked the driving out of LRA forces from Uganda amidst threats of ICC prosecutions against their leaders (Allen, 2006), as well as the return of multi-party politics. With people allowed to return to their villages and resume their livelihood activities, the north has experienced a peace dividend, as evidenced by a significant fall in the poverty headcount. This dynamic has been further shaped by the move towards establishing the independent state of Southern Sudan, which offered a huge new market and new economic opportunities for northern Ugandans, particularly following the regeneration of Juba. In 2008, the government launched its Peace, Recovery and Development Plan (PRDP), although this failed to gain sufficient funding and still reflected a tendency to treat the north as a parallel problem, rather than as one integral to Uganda's political economy moving forward. However, a more muscular PRDP II was launched in 2010/11, and the north was also integrated more clearly into the National Development Plan launched in 2010, albeit within a discourse that retained a residual focus that blamed the region (and the north-east) for their poverty (Hickey, 2009, 2013). More importantly, the build-up to the 2011 elections offered the President a strong incentive to engage more positively with the north. His strategy included several 'poverty tours' of the region, which he used to generate goodwill through a mixture of rent-sharing/vote-buying and the disbursal of development funds for roads, bridges and hospitals. There is also a growing sense (which requires further investigation) that the regime has successfully co-opted growing numbers of northern elites into the ruling coalition through national-level posts. This has been enabled in part by the rise of a new generation of educated northerners, who do not share the antipathy of their forbearers to the NRM.

These closely related advances in terms of security, development and political inclusion seem to have influenced the remarkable turnaround witnessed at the 2011 polls, with the region offering majority support for the President and the government in both the executive and legislative elections. This seems to show how the logic of electoral politics under a multi-party dispensation has led to the regime employing strategies associated with competitive clientelism to shore up a dominant party settlement. This has involved bringing the north within the orbit of the ruling coalition, and arguably making the political settlement more 'inclusive' (Parks and Cole, 2010), in ways that are largely compatible with inclusive development outcomes, albeit for largely instrumental political purposes. 
Investigating the links between political settlements and inclusive development in Uganda

\subsection{Summary}

The political settlement in Uganda contains few incentives for political elites to ensure that effective, impersonal and accountable institutions emerge and are allowed to function. This has the effect of reducing the capacity and commitment of the state to deliver development and structural transformation. Prime examples include accelerated districtisation, an apparent erosion of the few pockets of bureaucratic excellence in public service terms, a flatlining tax-take and a poor and worsening record on delivering public goods and implementation across the board. There is also something of a vicious circle at work here, whereby the relatively slow rate of structural transformation stymies the creation of more autonomous economic interest groups and urbanisation, which is linked to catalysing processes associated with improved levels of democracy and governance (Khan, 2005, 2010).

The return of multi-party politics has further politicised public policy making and has both deepened and broadened the level, and the costs, of patronage, thus reducing the availability of resources for productive investments. However, the deepening of electoral incentives heralded by the return to multi-party politics has also meant that, to some extent and in some areas at least, the terms of inclusion within the ruling coalition are being re-negotiated, most notably regarding the north and in ways that appear to be deepening elite commitment towards inclusive development. Also, and as predicted by Levy (2012), even within such clientelistic settlements there remains at least some room for manoeuvre in certain policy spaces, particularly those involving existing pockets of bureaucratic excellence (e.g. MFPED, Bank of Uganda). Some bureaucrats in key positions remain committed to ensuring that evidence-based development policies are made and delivered, and there is some room here (in the realm of ideas and strategic thinking) for external brokers to engage.

\section{Uganda's transnational politics of development}

The politics of development in Uganda has and will continue to be closely shaped by transnational factors, particularly the character and level of its integration into wider transnational flows and institutions and relationships with external actors, from the regional to the global level. This operates not only at the ideational level, in terms of influence over the development policy agenda, but also at the level of the strategies employed by ruling coalitions to maintain themselves in power, which have involved the maintenance of key relationships not only with domestic, but also with transnational political actors. ${ }^{30}$

${ }^{30}$ For example, the two key areas of public service in Uganda which could be said to have improved their capacity and effectiveness to deliver their functions under the current regime, namely the military and institutions of economic governance, have at least two things in common: both have been central to regime continuity; and both have involved strong international interests. The donor financing that has flowed in large amounts, to a large extent because of Uganda's 


\subsection{Regional issues: security and integration}

Since independence Uganda has experienced episodes of insecurity stemming not only from its own internal socio-economic and political contradictions, but also from its location in a historically conflict-ridden and politically volatile regional neighbourhood. In general terms, the region is going through a period of relative calm, although an outbreak of hostilities between Sudan and South Sudan would almost certainly see Uganda becoming involved on the side of the latter. However, although this would impose severe demands on Uganda's limited financial resources, it would not threaten political order at national level. It is important to note that the government of Uganda operates very strategically on this front. For example, sending troops into Somalia enabled Museveni to retain the strong support of the United States, which has poured considerable resources into building the capacity of the UPDF in ways that have enhanced regime stability.

The deepening of regional integration in the East African Community promises to have largely positive implications for the politics of development in Uganda, and could be a driver of higher levels of capacity and commitment to development in Uganda, helping to build stronger institutional foundations as sound policies become promoted and protected by regional-level stakeholders from the business community in particular (ODI, 2006). Increased integration may help to generate more incentives amongst political elites to focus on Uganda's development performance in the spirit of patriotic competition with neighbours (as appears to have happened in East Asia).

\subsection{How does aid shape the politics of development in Uganda? Some key trends}

Although of declining importance within Uganda's new political economy, aid retains a level of significance in economic, political and strategic terms. Aid currently constitutes around 30 per cent of Uganda's annual budget, which marks a significant reduction as compared the earlier 2000s, when donors financed around half of the budget. The mid2000s marked an important turning point for aid relations and the political economy of development within Uganda more broadly, particularly in terms of the following shifts (Hickey, 2013):

reputation for high levels of capacity and probity in economic governance, has been critical to enabling the regime to deliver populist policy promises and maintain an expensive patronage machine (see below). Somewhat similarly, the professionalisation of the military over recent years, supported by key allies such as the United States, has played the dual role of ensuring that the regime is well protected from any threats (internal or external) and has also enabled Uganda to offer troops to international peacekeeping forces, most notably in Somalia. This has gained the regime a high degree of political capital on the international scene with certain western powers, who have in turn maintained high levels of aid and remained fairly uncritical of the regime. 
- Uganda's graduation from international indebtedness, declining reliance on aid and withdrawal from debt-related policy conditionality;

- worsening donor-government relations around governance and democracy issues, particularly the regime's repressive approach to the opposition around the 2006 multi-party elections;

- the discovery of significant oil reserves; and

- the growing role of non-traditional donors and particularly China (e.g. following Uganda's signature of the Sino-Africa Pact in 2006).

The shifts have heralded a difficult period for donor-government relations. On the one hand, the President has become increasingly dismissive of the advice and resources offered by 'traditional' donors, and the new forms of conditionality associated with direct budgetary support (DBS). On the other, several donors have responded to high-level corruption scandals and weak performance around service delivery by reducing their levels of DBS. ${ }^{31}$

The increased role played by China and other 'rising powers' offers the government of Uganda alternative sources of finance and a different way of doing business. Senior government officials see China as central to financing the major infrastructural investments required for the new agenda of structural transformation, leaving more traditional donors to support the social sectors. ${ }^{32}$ It remains to be seen whether aid from China is significantly altering the dynamics of governance and development in Uganda (Mohan, 2012), not least as these are already closely informed by the geopolitics of aid, particularly concerning Uganda's military support for the US and its allies in Somalia and its status as a relatively stable force in an otherwise unstable region. This has significant effects on the extent to which certain powers have the incentive to critically engage the regime around sensitive governance issues.

\footnotetext{
${ }^{31}$ E.g. DFID forecasts that its DBS to Uganda will be only £5 million per annum by 2014.

${ }^{32}$ Reliable data on aid from China is difficult to come by, due to both transparency issues and the complex character of 'Chinese aid' (Brautigam, 2009;). In Uganda, it appears to focus on economic rather than social infrastructure and is characterised by a lack of rhetorical or programmatic focus on democracy, human rights and good governance, a tendency to limit conditionality to strategic self-interest (e.g. the granting of contracts to Chinese firms and the use of Chinese labour), and a reluctance to coordinate efforts within the auspices of OECD/DAC. However, in other respects there is a significant level of similarity between China's approach, motives and interests and those of some more 'traditional' donors, most strikingly the United States. For example, both have strong interests in gaining a strong foothold in the country for their exports and to ensure regional stability (particularly given interests in oil and trading routes within the region), whilst also seeking to secure support for their influence and ambitions within global arenas (e.g. the UN). There is an increasing ideological convergence between China and traditional donors, and particularly the World Bank, around Uganda's project of 'structural transformation'.
} 
Donors appear to have been more successful at influencing GoU at the level of policy ideas and development than in securing institutional change. Following an initial dalliance with socialist policies after taking power in 1986, the NRM regime has successively adopted the main donor-driven policy consensus of the time, from the structural adjustment policies of the Washington Consensus through the good governance reforms and poverty focus of the Post-Washington Consensus that took hold in the late 1990s. This reflects a pragmatic response to the realities of aid dependence and debt-related lending but also the leadership's underlying commitment to promoting development as part of an effort to rebuild state legitimacy. Despite government of Uganda's claims that its recent shift to a focus on structural transformation, as heralded in the National Development Plan (NDP), marks a departure from donor-influenced policy agendas, external influence is still apparent. The current and more productivist policy agenda indicates a new convergence between the President's longstanding attachment to 'modernisation' and the structural transformation focus of both China and the World Bank, whose 2008 Country Memorandum on the subject directly shaped the NDP (Hickey, 2013).

Donor-led efforts to strengthen Uganda's institutional capacity have been closely linked to these efforts to steer economic policy making, with significant investments in the Ministry of Finance and the Bank of Uganda, both of which helped Uganda to establish macro-economic stability, and (to a lesser extent) the Uganda Revenue Authority. Each exhibits high-level technical expertise and a relatively significant degree of autonomy from political pressure, reflecting their role in maintaining the level of economic order deemed necessary by the executive to underpin the continuity of the ruling coalition, including in terms of transnational support.

In areas of governance deemed less critical to the regime's interests, donor efforts to promote higher levels of capacity and accountability have been largely unable to overcome the political incentives created by the prevailing political settlement. Uganda now has a plethora of accountability institutions, although these have generally been either captured or rendered ineffective by the political incentives established by Uganda's political settlement, thus deepening rather than alleviating the country's governance problems. In terms of service delivery, over a decade of sector-wide approaches appear to have led to little systematic improvement in terms of effectiveness and accountability. This holds within health (Wild and Domingo, 2010) and education (Dauda, 2004), although the water sector is said to have experienced greater progress (JIMAT, 2011). The critical sectors in terms of the modernisation agenda, including agriculture and roads, remain beset by deep levels of patronage and political interference (see Kjaer and Muhumuza, 2009; and Booth and Golooba-Mutebi, 2009, respectively), particularly since the return of multi-party politics. 
Development aid appears to have helped sustain rather than challenge the patronage mode of politics in Uganda (Barkan, 2011; Mwenda and Tangri, 2005; Tripp, 2010). This flows from a generic problem regarding the nature of aid and also from the specific dynamics of aid relationships in Uganda. In general terms, "...states which can raise a substantial proportion of their revenues from the international community are less accountable to their citizens and under less pressure to maintain popular legitimacy" (Moss, Pettersson and van de Walle, 2006). They also face fewer incentives to generate revenue from taxation, which has historically led to stronger forms of state-society bargaining and accountability (Brautigam et al., 2008). Aid also offers considerable rentseeking opportunities, and specific policy guidance from donors (e.g. on privatisation) has been directly linked to the deepening of high-level corruption in Uganda (Tangri and Mwenda, 2010). A recent study of the impact of Paris Declaration principles on accountability in the health sector in Uganda and Zambia found that "Domestic accountability institutions and actors generally seem to remain untouched by the aid effectiveness agenda" (Wild and Domingo, 2010, p. vii).

Overall, Uganda's location within specific geopolitical relationships is undergoing transition on a number of economic, diplomatic and security fronts. Developments in this transnational arena will continue to closely inform the political possibilities for development in Uganda, particularly around oil and the flow of ideas that continue to shape development strategy and policies.

\section{Conclusion}

Recent research strongly suggests that a political settlements approach can provide important insights into the politics of development in Uganda. This includes work on agriculture and other productive sectors (Kjaer and Joughin, forthcoming; Kjaer and Katusiimeh, 2012) and also on the north (Lindemann, 2010). This paper has also made some headway in showing not only how the approach may also help to explain developments in other sectors, including oil, social provisioning and gender, but also how the role of ideas has been closely entwined with the more material and instrumental aspects of building coalitions and maintaining power in Uganda. Moreover, there are some very interesting dynamics at play which offer room for some interesting theoretical work. In processes that may well be related, Uganda has: (a) moved from a situation where politics seemed to be broadly aligned with an agenda of inclusive development, to one where most observers are convinced that its developmental orientation is in decline; and (b) experienced a deepening of tendencies associated with competitive clientelism, although still within a dominant leader political settlement within which the President remains the hegemonic centrifugal force. This raises interesting typological issues concerning the internal differentiation of the main types identified by Levy (2012), and offers the possibility of identifying how dynamic change within political settlements reshapes the capacity and commitment of governments to deliver inclusive 
Investigating the links between political settlements and inclusive development in Uganda

development. This in turn can provide grounds for developing new hypotheses for future research. Appendix 1 sets out some potential research projects with reference to ESID's main research programmes which could provide interesting and comparative areas for further investigation. 
Investigating the links between political settlements and inclusive development in Uganda

\section{References}

Ahimbisibwe, P. (2012). 'Commission starts inquiry into 750 cases of abuse of UPE funds'. Daily Monitor, 19 April.

Allen, C. (1995). 'Understanding African Politics'. Review of African Political Economy, 22: $301-320$.

Allen, T. (2006) Trial Justice: The ICC and the LRA. London, UK: Zed Books).

Atkinson, R. R. (1994). The Roots of Ethnicity: The Origins of the Acholi of Uganda before 1800. Kampala: Fountain Publishers.

Barkan, J. (2011). 'Uganda: assessing risks to stability'. A Center for Strategic and International Studies Report. Washington DC: CSIS.

Batageka, L. and J. M. Matovu (2011). 'Oil wealth and potential Dutch Disease effects in Uganda', EPRC Working Paper. Kampala: Economic Policy Research Centre.

Booth, D. (2011). Working with the Grain and Swimming against the Tide: Barriers to Uptake of Research Findings on Governance and Public Services in Low-income Africa. London: Africa Power and Politics Programme.

Booth, D. and F. Golooba-Mutebi (2009). 'The political economy of roads reform in Uganda'. ODI Working Paper 207. London: ODI.

Branch, A. (2005). Neither peace nor justice: political violence and the peasantry in Northern Uganda, 1986 report. Washington DC: CSIS.

Brautigam, D. (2009). The Dragon's Gift: The Real Story of China in Africa. Oxford: Oxford University Press.

Bräutigam, D., O. Fjeldstad and M. Moore (eds.) (2008). Taxation and State-Building in Developing Countries: Capacity and Consent. Cambridge, UK: Cambridge University Press.

Bukenya, B. (2012). 'The politics of service delivery'. University of Manchester: PhD Thesis.

Collier, P. (2011). 'Managing Uganda's oil discovery'. Oxford Centre for the Study of African Economies, Department of Economics, Oxford University. Mimeo. 
Investigating the links between political settlements and inclusive development in Uganda

Dauda, C. L. (2004). 'The importance of de facto decentralization in primary education in Sub-Saharan Africa PTAs and local accountability in Uganda', Journal of Planning Education and Research 24, pp. 28-40.

Di John, J. and J. Putzel (2009). 'Political settlements: Issues paper', Governance and Social Development Resource Centre, University of Birmingham, UK, June.

Dodge, Cole P, and Paul D Wiebe (Eds.). 1985. Crisis in Uganda: The breakdown of health services. Oxford: Pergamon Press.

Evans, P. (1995). Embedded Autonomy: States and Industrial Transformation. Princeton, NJ: Princeton University Press.

Finnstrom, S. (2003). Living with Bad Surroundings: War and Existential Uncertainty in Acholiland, Northern Uganda. Uppsala Studies in Cultural Anthropology 35, Uppsala University, Uppsala

Fox, L. (2009). 'Sharing the growth in Uganda: Recent labor market outcomes and poverty reduction'. Mimeo.

Gingyera-Pinycwa, G. A. (1978). Apolo Milton Obote and His Times. Lagos: NOK Publishers.

Goetz, A. M. and Hassim, S. (eds.) (2003). No Shortcuts to Progress: African Women in Politics and Policy-making. London, UK: Zed.

Golooba-Mutebi, F. (2005) 'When Popular Participation Won't Improve Service Provision: Health Care in Uganda'. Development Policy Review 23 (4), pp.165-182.

Golooba-Mutebi, F. (2008). 'Collapse, War and Reconstruction in Uganda: An Analytical Narrative on State Making', Working Paper No. 27: Crisis States Research Centre, London: London School of Economics and Political Science.

Golooba-Mutebi, F. (2009). 'When Neither Parties Nor Parliament Deliver on Accontability: Lessons from Uganda'. Paper delivered at the 'Sources of Accountability on the African Continent' conference, University of Cape Town. July 20-24.

Golooba-Mutebi, F. (2011). 'Voting for peace, goods, and out of fear: Uganda's 2011 presidential elections'. Discussion paper: Makerere Institute of Social Research. 
Investigating the links between political settlements and inclusive development in Uganda

Golooba-Mutebi, F. (2012). 'In search of the right formula: Public private and communitydriven provision of safe water in Rwanda and Uganda'. Public Administration and Development, 32(4-5), pp. 430-433.

Golooba-Mutebi, F. and S. Hickey (2010) 'Governing chronic poverty under inclusive liberalism: the case of the Northern Ugandan Social Action Fund', Journal of Development Studies, 46(7): 1216-39.

Goodfellow, T. and K. Titeca (2012). 'Presidential intervention and the changing "politics of survival" in Kampala's informal economy'. Cities 29(4), pp. 264-270.

Gore, C. (2000). 'The rise and fall of the WC as a paradigm for developing countries', World Development, 28(5), pp. 789-804.

Gukiina, Peter M. 1972. Uganda: A Case Study In African Political Development. London: University of Notre Dame Press.

Hansen, H. B. and M. Twaddle (eds.) (1991). Changing Uganda. London: James Currey.

Hickey, S. (2005). 'The politics of staying poor: Exploring the political space for poverty reduction in Uganda'. World Development, 33(6), pp. 995-1009.

Hickey, S. (2009). 'Rethinking poverty analysis from the margins: Insights from northern Uganda'. Afriche e Orienti, XI(ii), pp. 119-136.

Hickey, S. (2012a). 'Investigating the politics of inclusive development: Towards a relational approach'. ESID Working Paper, No.1. Manchester: ESID.

Hickey, S. (2012b). 'Beyond "Poverty Reduction through Good Governance": Insights from the new political economy of development in Africa'. New Political Economy, 17(5), pp. 683-690.

Hickey, S. (2013). 'Beyond the poverty agenda? Insights from the new politics of development in Uganda', World Development, 43(1): 194-206.

Hunt, D. (2004). 'Unintended consequences of land rights reform: the case of the 1998 Uganda Land Act'. Development Policy Review, 22(2), pp. 173-191.

ICG (2012). 'Uganda: No resolution to growing tensions'. International Crisis Group Africa Report N¹87, 5 April 2012. Nairobi/Brussels: ICG.

Izama, A. (2011). 'Uganda: Museveni's triumph and weakness'. Journal of Democracy, 22(3), pp. 64-78. 
Investigating the links between political settlements and inclusive development in Uganda

JIMAT (2011). Phase II Evaluation of the Implementation of the Paris Declaration in Uganda. Kampala: OPM, Government of Uganda.

Kasekende, L. A, M. A. Ego and R. K. Sebudde (2004). 'The African growth experience: Uganda country case study'. AERC Working Paper No. 8. Nairobi: AERC.

Kasfir, N. (1991). 'The Ugandan elections of 1989: power, populism and democratisation', in H. B. Hansen and M. Twaddle (eds.), Changing Uganda (pp. 247-278). Oxford/Kampala: James Currey/Fountain Publishers..

Kathman, J. and M. Shannon (2011). 'Oil extraction and the potential for domestic instability in Uganda'. African Studies Quarterly, 12(3), pp. 23-45.

Khan, M. (2010). 'Political settlements and the governance of growth-enhancing institutions'. Mimeo. London: SOAS.

Khan, M. (2004). 'State failure in developing countries and institutional reform strategies', in Tungodden, M. N. Stern and I. Kolstad (eds.), Towards Pro-Poor Policies: Aid, Institutions and Globalization (pp. 165-195). Washington, DC: World Bank.

Khan, M. H. (2005). ‘Review of DFID’s Governance Target Strategy Paper'. Mimeo.

Kjaer, A. M. and M. Katusiimeh (2012). 'Growing but not transforming: Fragmented ruling coalitions and economic developments in Uganda'. DIIS Working Paper. Copenhagen: Danish Institute for International Studies.

Kjaer, A. M. and Muhumuza, F. (2009). 'The New Poverty Agenda in Uganda'. DIIS Working Paper 2009: 14. Copenhagen: Danish Institute for International Studies.

Kjaer, A. M. and Joughin, J. (forthcoming). 'The reversal of agricultural reform in Uganda: Ownership and values', Policy and Society.

Kjær, A. M. and O. Therkildsen (2012). 'Elections and landmark policies in Uganda and Tanzania'. Democratization, forthcoming.

Kobusingye, O. (2010). The Correct Line? Uganda under Museveni. London: Author House.

Kuteesa, F., E. Tumusiime-Mutebile, A. Whitworth and T. Williamson (eds.) (2010). Uganda's Economic Reforms: Insider Accounts. Oxford: Oxford University Press. 
Investigating the links between political settlements and inclusive development in Uganda

Leopold, M. (2005). Inside West Nile. Oxford/Kampala: James Currey/Fountain Publishers.

Levy, B. (2012, forthcoming). Working with the Grain: Integrating Governance and Growth in Development Strategies (draft manuscript, available from author).

Lindemann, S. (2010) 'Exclusionary elite bargains and civil war onset: the case of Uganda', Crisis States Working Papers Series 2 76. London: Crisis States Research Centre,

Makara, S., Rakner, L. and Svasand, L. (2009). 'Turnaround: the NRM and the reintroduction of a multiparty system in Uganda'. International Political Science Review, 30(2), pp. 185-204.

Mamdani, M. (1996). Citizen and Subject. Princeton, NJ: Princeton University Press.

Mazrui, A. A. (1991). 'Privatisation versus the market: cultural contradictions in structural adjustment', in H. B. Hansen and M. Twaddle (eds.), Changing Uganda (pp. 351378). Oxford/Kampala: James Currey/Fountain Publishers.

MFPED (2012). Poverty Status Report. Kampala: Government of Uganda.

MFPED (2010). MDG Progress Report. Kampala: Government of Uganda.

MFPED (2008). The Poverty Action Fund (PAF) Reform. Kampala: Republic of Uganda.

Mohan, G. (2012) 'China in Africa: impacts and prospects for accountable development. ESID Working Paper No. 12. University of Manchester, UK; Manchester. Available from www.effective-states.org.

Mosley, P. (2012). The Politics of Poverty Reduction. Oxford: Oxford University Press.

MOWE (2012). Climate Change Strategy for Water Sector. Kampala: Ministry of Water and Environment.

Moss, T., G. Pettersson and N. van de Walle (2006). 'An aid-institutions paradox? A review essay on aid dependency and state building in Sub-Saharan Africa'. CGD Working Paper 74. Washington, DC: Centre for Global Development.

Mubangizi, M. (2011). 'Museveni woos traders with cash'. Observer, Sunday 7 August. 
Investigating the links between political settlements and inclusive development in Uganda

Mugenyi, J. (1991). 'IMF conditionality and structural adjustment under the National Resistance Movement', in H. B. Hansen and M. Twaddle (eds.), Changing Uganda (pp. 61-77). Oxford/Kampala: James Currey/Fountain Publishers.

Mutibwa, P. (1992). Uganda since Independence: A Story of Unfulfilled Hopes. London: C. Hurst \& Co Publishers.

Mwenda, A. and R. Tangri (2005). 'Patronage politics, donor reforms, and regime consolidation in Uganda'. African Affairs, 104(416), pp. 449-467.

Mwenda, A. and R. Tangri (2001). 'Corruption and cronyism in Uganda's privatisation in the 1990s'. African Affairs, 100, pp. 117-133.

Neema, S.B. (1994) 'Mothers and Midwives: Maternity Care Options in Ankole, Southwestern Uganda'. PhD Dissertation: Institute of Anthropology, University of Copenhagen, Denmark.

Njuba, S. K. (1991). 'Legal adjustment to revolutionary change', in H. B. Hansen and M. Twaddle (eds.) Changing Uganda (pp. 210-216). Oxford/Kampala: James Currey/Fountain Publishers.

North, D. C., J. J. Walliss and B. R. Weingest (2009). Violence and Social Orders: A Conceptual Framework for Interpreting Recorded Human History. Cambridge, UK: Cambridge University Press.

Nugent, P. (2010). 'States and social contracts in Africa'. New Left Review, 63, pp. 3568.

Nyilinkindi, E. and M. Opagi (2010). 'Privatisation and parastatal reform', in E. Kuteesa, E. Tumusiime-Mutebile, A. Whitworth and T. Williamson (eds.), Uganda's Economic Reforms: Insider Accounts. Oxford: Oxford University Press.

Ochieng, E. O. (1991). 'Economic adjustment programmes in Uganda, 1985-8', in H. B. Hansen and M. Twaddle (eds.), Changing Uganda (pp. 43-60). Oxford/Kampala: James Currey/Fountain Publishers.

ODI and Regional Partners (2006). Understanding the Political Economy of Integration in East Africa. Report commissioned by the Africa Policy Department/Pan-Africa Unit, DFID. 
Investigating the links between political settlements and inclusive development in Uganda

Oloka-Onjango, J. (2000) 'New wine or new bottles? Movement politics and onepartyism in Uganda', in J. Mugaju and J. Oloka-Onjango (eds) No-party democracy in Uganda: myths and realities. Kampala: Fountain Publishers.

Pankhurst, D. (2002). 'Women and politics in Africa: The case of Uganda'. Parliamentary Affairs, 55(1), pp. 119-128.

Parks, T. and W. Cole (2010). 'Political settlements: Implications for international development policy and practice'. The Asia Foundation Occasional Paper No. 2.

Passi, Fabius O. 1995. "The rise of People's Organisations in Primary education in Uganda." Pp. 209-22 in Service provision under stress in East Africa: The state, NGOs and People's Organizations in Kenya, Tanzania and Uganda, edited by Joseph Semboja and Ole Therkildsen. Kampala: Fountain Publishers.

Poteete, A. R. (2009). 'Is development path dependent or political? A reinterpretation of mineral-dependent development in Botswana', Journal of Development Studies, 45(4), pp. 544-571.

Pritchett, L. and E. Werker (2012). 'Developing the guts of a GUT (Grand Unified Theory): Elite commitment and inclusive growth'. ESID Working Paper No 6. Manchester: ESID.

Robinson, M. (2006). 'The political economy of governance reforms'. IDS Discussion Paper 386. Brighton, UK: IDS.

Ross, M. L. (2012). The Oil Curse: How Petroleum Wealth Shapes the Development of Nations. Princeton, NJ: Princeton University Press.

Rubongoya, J. B. (2007). Regime Hegemony in Uganda: Pax Musevenica. New York and Basingstoke: Palgrave MacMillan.

Sandbrook, R., Edelman, M., Heller, P. and Teichman, J. (2007). Social Democracy in the Global Periphery. Cambridge, UK: Cambridge University Press.

Selassie, A. A. (2008). Beyond Macroeconomic Stability: The Quest for Industrialization in Uganda. Washington, DC: International Monetary Fund.

Southall A. (1998). 'Isolation and underdevelopment: Periphery and centre', in H. B. Hansen and M. Twaddle (eds.), Developing Uganda. Oxford/Kampala: James Currey/Fountain Publishers. 
Investigating the links between political settlements and inclusive development in Uganda

Sjogren, A. (2007) 'Between Militarism and Technocratic Governance: State Formation in Contemporary Uganda'. Doctoral Thesis in Political Science at Stockholm University, Sweden.

Ssenyange, E. (2010). 'South-South development co-operation: A challenge to traditional aid relations?' In Reality of Aid, Special Report on South-South Development Co-operation. Philippines: IBON Books.

Talemwa, M. (2010). 'Made in China'. Observer, 1 December.

Tamale, S. (1999). When Hens Begin to Crow: Gender and Parliamentary Politics in Uganda. Kampala: Fountain.

Tangri, R. and A. Mwenda. (2010). 'President Museveni and the politics of presidential tenure in Uganda', Journal of Contemporary African Studies, 28(1): 31-49.

Thompson, G. (1999). Governing Uganda: British Colonial Rule and its Legacy. Kampala: Fountain Publishers.

Tripp, A. M. (2001). 'The politics of autonomy and co-optation in Africa: The case of the Uganda Women's Movement'. Journal of Modern African Studies 39(1), pp. 101128.

Tripp, A. M. (2010). Museveni's Uganda: Paradoxes of Power in a Hybrid Regime. Boulder, CO: Lynne Reinner.

Tumushabe, G. (2011). Critical Reflections on Oil Governance Discourse in Uganda. Kampala: Africa Centre for Media Excellency.

Tumusiime-Mutebile, E. (2010). 'Institutional and political dimensions of economic reform', in F. Kuteesa, E. Tumusiime-Mutebile, A. Whitworth and T. Williamson (eds.), Uganda's Economic Reforms; Insider Accounts (pp. 35-51). Oxford: Oxford University Press.

Twinomugisha, B.K. (2004) 'Protection of Rural Poor Women's Right to Maternal Care in Uganda: The Case of Kashambya Sub-County, Kabale District'. PhD Dissertation, Faculty of Law, Makerere University, Uganda.

UNHDS (2012). Uganda National Health and Demographic Survey. Kampala: Government of Uganda.

Vokes, R. (2012). 'Briefing: The politics of oil in Uganda'. African Affairs, 111(443). 
Investigating the links between political settlements and inclusive development in Uganda

Vom Hau, M. (2012) State capacity and inclusive development: new challenges and directions. ESID Working Paper No. 2. Manchester: ESID.

van Zwanenberg, R. M. A and A. King (1975). An Economic History of Kenya and Uganda, 1800-1970. London: Palgrave-Macmillan.

Wild, L. and P. Domingo (2010). Accountability and Aid in the Health Sector. London:ODI/World Vision.

World Bank (2007). Uganda; Beyond Recovery. World Bank Country Economic Memorandum. Washington, DC: World Bank.

World Bank (2010). Uganda; Country Assistance Strategy. Washington, DC: World Bank.

World Bank (2012) Uganda: Promoting Inclusive Growth: Transforming Farms, Human Capital and Economic Geography. Synthesis Report. World Bank (PREM, Africa Region): Uganda. 
Investigating the links between political settlements and inclusive development in Uganda

\section{Appendix 1: Some suggestions for ESID research in Uganda}

\section{Programme 1: Concepts, Theory and Measurement}

- How do changes in the political settlement re-shape capacity for and commitment to delivering development over time?

- How do dynamic shifts within and between different types of political settlement play out and with what implications for capacity and commitment?

- How are ideas entwined within the formation of political settlements and how do they help shape their implications for inclusive development?

\section{Programme 2: the politics of accumulation}

- The politics of oil

- How is oil being governed within the current political settlement? How is oil reshaping the contours and functioning of the ruling coalition?

- Which ideas are shaping the governance of oil and how is the presence of oil reshaping the political imaginary in Uganda?

- What role are transnational actors playing here and with what impacts on the political settlement? What are the national-local and intra-local dynamics involved here, and what implications do they have for the nature and functioning of the political settlement at different levels?

- What implications does oil have for inclusive development in Uganda? In particular, what will be the implications for agriculture, infrastructure and social sector investments?

- Growth, structural transformation and employment

- The political dynamics of growth

- Agriculture?

Programme 3: the politics of redistribution through social provisioning

- To what extent and in what ways does the over-arching political settlement and the dynamics therein shape the delivery of high quality goods on the social sectors (e.g. health, education)?

Programme 4: the politics of recognition

- What is the gendered character of the political settlement in Uganda, and how does this shape: (a) women's political participation; (b) gender equity policies; and (c) the relationship between these?

- What implications does the changing character of the political settlement under multi-partyism have for the northern region of Uganda? What strategies have been used to bring the north within the political settlement and with what implications for politics and development? 
Investigating the links between political settlements and inclusive development in Uganda

Programme 5: transnational (NB: this will also cut across each of the above)

- To what extent has political economy analysis informed donor programming around good governance in Uganda and with what effects?

- Given the historic influence of external actors over development policy ideas in Uganda, what scope is there for increasing capacities and commitment around promoting structural transformation? Action research?

- To what extent can donors drive up political commitment to social protection (case-study of SAGE)? 


\section{esid}

\section{The Effective States and Inclusive Development Research Centre}

The Effective States and Inclusive Development Research Centre (ESID) aims to improve the use of governance research evidence in decision-making. Our key focus is on the role of state effectiveness and elite commitment in achieving inclusive development and social justice.

ESID is a partnership of highly reputed research and policy institutes based in Africa, Asia, Europe and North America. The lead institution is the University of Manchester.

The other founding institutional partners are:

- $\quad$ BRAC Development Institute, BRAC University, Dhaka

- Institute for Economic Growth, Delhi

- Department of Political and Administrative Studies, University of Malawi, Zomba

- $\quad$ Center for Democratic Development, Accra

- $\quad$ Centre for International Development, Harvard University, Boston

In addition to its institutional partners, ESID has established a network of leading research collaborators and policy/uptake experts. 